NBER WORKING PAPER SERIES

\title{
DOES COMPARABLE WORTH WORK IN A DECENTRALIZED LABOR MARKET?
}

\author{
Michael Baker \\ Nicole M. Fortin \\ Working Paper 7937 \\ http://www.nber.org/papers/w7937
NATIONAL BUREAU OF ECONOMIC RESEARCH
1050 Massachusetts Avenue
Cambridge, MA 02138
October 2000

The paper was previously circulated under the title "Comparable Worth Comes to the Private Sector: The Case of Ontario." We thank Joanne Roberts for helpful discussions, Charlie Beach, Barry Hirsch, Caroline Weber and seminar participants at the BALE Workshop (Spring 1999), the CEA (2000) annual meetings, the University of Chicago, the NBER Summer Institute (2000), the SOLE (1999) annual meetings, the University of Washington and Yale University for comments, and Garnett Picot, René Morissette, and Steve Roller of Statistics Canada for facilitating our access to the data. Ali Bejaoui and Elisabeth Reynolds provided excellent research assistance and bibliographic assistance, respectively. Financial support was provided by CIRANO, HRDC, SSHRC (Baker: Grants \#410-96-0187 and \#410-99-0112, Fortin: Grants \#410-96-0651 and \#410-99-0959), FCAR Québec and UC-Davis. The views expressed are those of the authors and not necessarily those of the National Bureau of Economic Research.

(C) 2000 by Michael Baker and Nicole M. Fortin. All rights reserved. Short sections of text, not to exceed two paragraphs, may be quoted without explicit permission provided that full credit, including $(\mathrm{C}$ notice, is given to the source. 
Does Comparable Worth Work in a Decentralized Labor Market?

Michael Baker and Nicole M. Fortin

NBER Working Paper No. 7937

October 2000

JEL No. J16, J38, J78

\begin{abstract}
$\underline{\text { ABSTRACT }}$
We investigate the effect of pro-active comparable worth legislation-covering both the public and private sectors-on wages, the gender wage gap and the gender composition of employment. The focus is the pay equity initiative of the Canadian province of Ontario in the early 1990s. We document substantial lapses in compliance and problems with the implementation of the law among smaller firms where the majority of men and women work. This evidence provides important lessons of the obstacles to extending pay equity to the private sector of a decentralized labor market. When we focus on those sectors of the labor market where compliance was relatively strict, our results suggest that any positive effects on the wages of women in female jobs were very modest. Our most consistently estimated effects of the law on wages are negative: slower wage growth for women in male jobs and for men in female jobs.
\end{abstract}

Michael Baker

Department of Economics

University of Toronto

150 St. George Street

Toronto ON, Canada

M5S 3G7

and NBER

baker@chass.utoronto.ca
Nicole M. Fortin

Department of Economics

University of British Columbia

\#997-1873 East Mall

Vancouver BC, Canada

V6T 1Z1

and CIRANO

nifortin@interchange.ubc.ca 


\section{INTRODUCTION}

In developed economies, pay equity/comparable worth programs are a common public policy response to gender wage differentials. Equal pay for work of equal value is a "basic right" in the European Union and is enshrined in Community law. The wage tribunals in Australia have long paid heed to the principle of comparable worth in wage determination. Pay equity is synonymous with the public sector in Canada and is now being extended to the private sectors of her two largest provinces. Finally, comparable worth has made many inroads in state and local governments in the United States. All but five states have initiated some level of pay equity activity, and eight states have implemented pay equity programs for their employees (Gardner and Daniel (1998)). Also, after more than a decade of neglect, comparable worth is re-emerging as a policy option at the federal level. For example, the Paycheck Fairness Act was endorsed in the State of the Union Address of January $2000 .^{2}$

Proponents have long viewed comparable worth legislation as an essential remedy to historical labor market discrimination against women and minorities. The U.S. National Committee on Pay Equity (NCPE) argues that the "wage gap exists because most women and people of color are still segregated into a few low-paying occupations". 3 Furthermore, these "jobs have historically been undervalued and continue to be underpaid because of the gender and race of the people who hold them".

Despite such endorsement and the widespread adoption of comparable worth policies, there is little direct evidence of whether pay equity programs reduce the gender wage gap at the aggregate level. Many of the arguments against the policy are theoretical (e.g., Killingsworth (1987)) or based in simulations (e.g., Beider, Bernheim, Fuchs and Shoven (1988), Ehrenberg and Smith (1987); Hundley (1992)). Many of the arguments for the

\footnotetext{
${ }^{2}$ The Paycheck Fairness Act would amend the Equal Pay Act, enhancing remedies for discrimination under the Act, providing more resources to the Equal Employment Opportunity Commission and allowing employees to freely discuss their salaries with their co-workers. The last decade has also seen the Fair Pay Act repeatedly submitted to Congress. This legislation would enable a more liberal interpretation of "equal value" (in the Equal Pay Act sense) than the courts have permitted.

${ }^{3}$ www.feminist.com/fairpay.htm.
} 
policy are extrapolations from isolated applications of comparable worth in the local public sector (Sorensen (1987)) to the entire labor market.

Some key questions are $i$ ) does a significant part of the gender wage differential result from gender segregation by occupation?, and if so ii) is comparable worth the appropriate policy response?, and if so iii) is comparable worth legislation a viable labor market regulation? There are a number of studies addressed to the first question, offering both larger (e.g., Johnson and Solon (1986)) and smaller (e.g., Macpherson and Hirsch (1995), Baker and Fortin (forthcoming)) estimates of the relationship between wages and the gender composition of employment. The answer to the second question is not clear, as some studies argue that an important component of the gender wage gap is due to wage differences across firms and industries, and thus outside the purview of comparable worth policies as traditionally conceived. Evidence to the third question is at best indirect. Comparable worth appears to "work" in the public sector (Orazem and Mattila (1990), O'Neill, Brien and Cunningham (1989)) or centralized labor markets such as Australia's (Borland (1999)). This is not to say the way is straight and clear: a recent three plus billion dollar pay equity settlement awarded to federal public sector workers in Canada was 16 years of negotiation and litigation in the making.

Our contribution in this paper is new evidence that fills important gaps in our answers to these questions. The focus is a recent extension of pay equity to the private sector in the Canadian province of Ontario. Through the Pay Equity Act, Ontario legislated a proactive application of comparable worth to public sector employers and all private sector employers of 10 or more employees. Ontario is a large province (11 million people) with a diversified economy. This episode, therefore, provides a unique opportunity to obtain direct evidence of the effect of comparable worth on a decentralized labor market.

The first part of the paper is directed to the third question: is comparable worth a viable labor market institution? Whether viewed positively or negatively, to be effective pay equity must be practical. This issue is less important for other labor market regulations such as minimum wages or overtime rates. ${ }^{4}$ In each of these cases the regulation is

\footnotetext{
${ }^{4}$ That said, investigations of the implementation of, and compliance with, labor market regulations are rare. See, for example Ashenfelter and Smith (1979).
} 
conceptually simple and external to the firm. Therefore, lapses in compliance are primarily the result of employer malfeasance. The difference here is that comparable worth involves the conceptually difficult step of making male and female jobs commensurate. The legislation can prescribe the principles by which these jobs should be compared, but not the specifics of the mechanism or the awards without assuming a dominant role in the firm's wage determination process. Many previous applications of this policy have been to single employers or to labor markets with centralized wage determination or strong centralized unions. We know very little of how this policy functions in a decentralized labor market.

Our findings here are striking: comparable worth appears to be a complicated and unwieldy labor market regulation. We document the resulting lapses in compliance with the Act that were substantial, especially among small firms. Not coincidently, it is these firms that lack the clearly delineated job classifications and personnel systems needed to perform pay equity comparisons. Commentary on the Ontario legislation reveals that the effective bite of the legislation was further blunted by the lack of male comparators for female jobs and the heterogeneity of comparable worth evaluation plans used by employers. These problems are far less likely to arise when pay equity is implemented in the public sector or in centralized labor markets, and a uniform pay equity plan can by applied to a large group of employees.

The second part of the paper is an empirical investigation of the effect of the Ontario law on wages, the gender wage gap, and the gender composition of employment. This is, to our knowledge, the first evaluation of the impact of comparable worth legislation on a decentralized labor market. Given the lapses in compliance, it is not surprising that we find the law had virtually no effect on aggregate wages in female jobs or the gender wage gap. Focusing on those sectors of the labor market where the legislation appeared to have the greatest bite, however, we find that any effects of the law tended to be negative rather than positive: it suppressed wage growth for women working in blue-collar male jobs.

In our evaluation we take advantage of the fact that other Canadian provinces can serve as a natural control group for evaluating the effect of the Ontario legislation. We also exploit systematic lapses in compliance with firm size to control for province specific trends. These are important considerations, as the lack of a suitable control group has hindered 
evaluation of past economy-wide implementations of pay equity (e.g., Killingsworth (1990)).

\section{How does Comparable Worth Work in a Decentralized \\ LABOR MARKET?}

\subsection{The Ontario Legislation}

Comparable worth was extended to the private sector of the Canadian province of Ontario through Pay Equity Act of $1987 .{ }^{5}$ The legislation covers both the public sector and firms in the private sector with 10 or more employees. It is pro-active, and provides a detailed timetable for employers to both post pay equity plans and to provide the initial payments of any necessary wage adjustments. It also guides implementation of comparable worth defining male and female job classes, acceptable methods of wage comparison and establishes the Pay Equity Commission as a overseer and arbiter of the legislation.

The details of this pay equity law are fairly standard. Women make up approximately 45 percent of the workforce; thus jobs comprising between $(45-15=) 30$ percent and $(45+15=)$ 60 percent of women are said to be integrated. Female job classes are those with $60 \%$ or more female workers while male jobs are at most $30 \%$ female. For the purposes of comparison the "value" of a job is determined on a gender neutral basis, using an index of skill, effort and responsibility requirements, as well as working conditions. Initially, male/female job comparisons were to be made within establishments on a job-to-job basis, between work of equal or comparable value. By 1993, the more common "wage-line" method (called "proportionate value") was allowed to accommodate situations where direct job-to-job comparisons were not possible. ${ }^{6}$ In addition, a proxy comparator method, restricted to the broader public sector, was implemented allowing male comparators to be found outside the establishment in cases that job-to-job or proportionate value comparisons failed. ${ }^{7}$

${ }^{5}$ The Act received Royal Assent in June 1987 and was proclaimed on January 1, 1988.

${ }^{6}$ In 1993 the Act was amended to permit both proportional value comparisons and the proxy method of locating comparators outside an organization. These amendments were announced by the Ontario Minister of Labor in December 1990. Employers were directed to use these new methods for all female job classes that were without a male comparator under the job-to-job method.

${ }^{7}$ A 1996 provincial act-The Saving and Restructuring Act-legislated a phase out of the proxy 
Differences in pay between jobs are tolerated on the following bases: seniority, temporary training assignments, merit pay, red-circling and skill shortages. Employers must be ready to justify any pay differences for these reasons. Finally, compensation cannot be reduced to attain pay equity.

The implementation of the Act was staggered across sectors and across private establishments of different sizes. ${ }^{8}$ It consisted of 1 ) the posting of a pay equity plan, and 2) the initiation of any wage adjustments. ${ }^{9}$ Pay equity plans were to be negotiated in establishments with bargaining units. In other establishments, the employer prepared and posted the plan which was then subject to review and possible appeal by employees. In either case, if the process ended in stalemate the Pay Equity Commission decided all outstanding issues. $^{10}$

The deadlines for different sectors and firms of different sizes are reported in Table 1. The tightest deadlines were for the public sector. In the private sector smaller firms received longer periods to comply with the law. Firms of less than 100 employees had a choice of posting a pay equity plan and making the initial pay equity awards one year later, or not posting a plan but paying the total award to achieve equity by this later deadline. For example, firms with 50-99 employees could post by January 1, 1993, and then make an initial award by January 1, 1994, or not post but make the total award by January 1, 1994. Finally, establishments with less than 10 employees were exempt from the Act.

The initial pro-active stage has been followed by a complaints stage in which firms are directed to maintain pay equity in the workplace. Changes in compensation that widen any

method starting in January 1997. In September 1997, however, the Ontario Court of Justice ruled that repealing the proxy method violated the Canadian Charter of Rights and Freedoms, and thus the repeal was "of no force or effect".

${ }^{8}$ The law defines an establishment as all of the employees of an employer employed in a geographic division. Unfortunately as later review of the law (Read (1996)) complains, the term "employer" is not defined in the law.

${ }^{9} \mathrm{~A}$ pay equity plan sets out the comparison system used, the job classes used, the results of the comparison, how compensation will be adjusted to compensate underpaid classes and the date of the first adjustment.

${ }^{10}$ Awards in a given year were limited to a maximum of one percent of the previous year's payroll. The method of adjustment is to be "bottom up" in the sense that the most severely underpaid female jobs are to receive larger increases. Payment of awards was to continue, however, until equity was achieved. 
differences in compensation between male and female jobs are prohibited. Finally, firms are directed to continue paying any outstanding awards until pay equity is achieved. ${ }^{11}$

\subsection{Enforcement and Compliance}

There is a sense in which the entire structure of the Ontario legislation is motivated by the failure of previous complaint-based pay equity laws to have any bite. ${ }^{12}$ In these programs, employees must register a complaint to trigger a comparison of male and female jobs and any consequent award. Fears that most employees would be too intimidated to register a complaint led to criticism that these sorts of policies were impotent. The Ontario law is instead pro-active. Employers must draw up a pay equity plan and make comparisons of male and female jobs whether or not any complaint has been made. Therefore, in principle, any inequities should be uncovered since the onus is on employers.

The responsibility for enforcement of the Act is given to the Pay Equity Commission which has two constituent parts: 1) the Pay Equity Office (PEO) charged with educating employers and employees about pay equity, monitoring compliance, providing dispute resolution services and issuing orders to resolve disputes, and 2) the Pay Equity Hearings Tribunal, which rules on disputes that arise under the Act, typically on reference from the PEO. The legislation specifies fines for both individuals and firms that ignore the Pay Equity Tribunal orders, impede a review officer, or coerce or penalize anyone acting under the legislation. To the dismay of some, there is no requirement that employers file their pay equity plans with the Commission. Firms are required, however, to inform the PEO of any female job classes that are ineligible for pay equity evaluation due to the lack of a male comparator, either on a job-to-job or proportionate value basis. ${ }^{13}$ The system is intended to be "self-monitoring", much like other labor market regulations.

${ }^{11}$ There are special rules governing the continuation of a pay equity plan on the sale of a business.

${ }^{12}$ Important here are the early experiences of the complaint based programs in Quebec and the federal sector. See, for example, Symes (1990) on the disappointment with this legislation.

${ }^{13}$ The cases are then referred to a Review Officer. The dispute resolution services of the PEO appear to be widely used, with between 1400 and 1700 open cases in a given month between January 1990 and December 1995 (Read (1996)). Monthly inflows and outflows averaged 50-100 cases during this period. 
Direct documentation on early compliance with the Act is provided by surveys commissioned by the PEO (SPR Associates (1991), Canadian Facts (1992) and (1993), Institute for Social Research (1994)). ${ }^{14}$ Each survey focuses on establishments of a specific size, and was conducted roughly 6-12 months after the relevant deadline for posting a pay equity plan. ${ }^{15}$ Unfortunately, it is difficult to compare the results across surveys due to differences in sample design and interviewing methods. The information collected on compliance with the posting deadline, however, appears to have a common basis. ${ }^{16}$

In Table 2 we report measures of compliance with the posting deadline by establishment size. The story here is that public sector employers and large private sector employers were much more likely to comply with the Law. Under 10 percent of these employers, compared to 20 percent of 50-99 employee firms and 80 percent of 10-49 employee firms, reported doing "no work" on pay equity. The 10 percent of public firms in this category are almost exclusively establishments of less than 100 employees. Furthermore, these statistics likely overstate the compliance of the smallest firms in the private sector. Roughly 37 percent of interviews of the smallest employers were abandoned because there was "little or no awareness about the legislation" (p. 30, ISR 1994). As a consequence the proportion of these employers who had done no work on pay equity is probably closer to 90 percent.

Similar inference is obtained from the numbers for full compliance: roughly one-half of public and large private establishments complied fully versus only 12-30 percent of smaller firms. The higher compliance of the largest private firms is even more impressive when weighted by female employment. For example, 91 percent of women working in establishments with 500 or more employees were employed in establishments that had

${ }^{14}$ Overviews of some or all of these surveys are provided in Gunderson (1995), Read (1996) and McDonald and Thornton (1998). MacDonald and Thornton conducted their own survey of 27 firms in the Toronto area in 1994. They document instances on non- compliance and manipulation of the rules, as well as some positive influences of the process.

${ }^{15}$ The survey of firms with 10-49 employees (ISR 1994) was conducted 15-18 months after the posting deadline.

${ }^{16}$ The survey of public sector employers and private sector employers with $500+$ employees was primarily completed by mail, although certain "key facts" on compliance were retrieved from non-respondents by telephone, courier and fax. In the surveys of smaller firms initial telephone surveys canvassed information on compliance, while further detail was collected by mail surveys which had a lower response rate. 
posted some or all of their plans. Recall that smaller employers had to decide by the posting deadline whether to post a plan. At the time of the survey, 45 percent of 50-99 employee firms and 83 percent of 10-49 employee firms had not yet made this decision. The strong message here is a lack of enthusiasm for the law in smaller firms.

Compliance is also correlated with union status. Some illustrative numbers for public and large private establishments are also reported in Table 2. In both the private and public sectors non-union firms were more likely to have all their plans posted. One reason for this discrepancy is that pay equity plans were negotiated in union shops. ${ }^{17}$

What were the reasons for these lapses in compliance? The surveys suggest that confusion about the law and the resource costs of pay equity plans played an important role. First, there were problems conducting the surveys because interviewees lacked understanding of the key requirements of the law and key dimensions of comparable worth such as "gender neutrality". These problems were particularly severe in small firms (Institute for Social Research (1994)). Second, the surveys provide information on factors impeding progress on pay equity for firms with 50-499 employees. Twenty-five (22) percent of firms with 100-499 (50-99) employees report resource costs as a factor. Seven (10) percent report confusion about the law as a problem. Finally, 17 (15) percent report the fact that no pay equity awards are needed as a reason, a proportion that is particularly high among firms that had done no work on pay equity!

Further inference from these surveys is limited. Additional information from firms with 50-499 employees (Canadian Facts (1992) and Canadian Facts (1993)) was collected by a subsequent mail survey, and the response rate appears to be correlated with compliance. ${ }^{18}$ That said, there are a few points worth noting. First, external consultants were an important input to compliance. In samples of firms that had done work on pay equity, roughly two-thirds of public and large private employers and 54 percent of firms with 100-499 employees reported hiring external consultants. In contrast, just 37 percent of firms with 50-99 employees and less than one-quarter of the very small number of 10-49 employee

${ }^{17}$ In firms of 100-499 employees 73 percent of non-union firms compared to 50 percent of union firms had posted all their plans. These results are from a mail survey (see below).

${ }^{18}$ For example, by the telephone survey 51 percent of $100-499$ employee firms had posted all their plans (table 2) compared to 64 percent according to the mail survey. 
firms that had completed some pay equity plans reported similar reliance on external help. Other criteria (e.g., purchase of new job comparison system) also indicate that smaller firms relied more on in-house expertise. ${ }^{19}$ Second, within the sample of firms with plans, clerical workers were the job group most often cited as eligible for, or having received an, award. The percentage of firms (or plans) reporting this ranges from 44 percent to 75 percent.

The surveys also document the difficulties finding male comparators in samples of firms with completed plans. The proportion of female job classes (FJC) and employees in FJC's without a male comparator are reported by firm size in Table 3 . The message here is that the impact of the law was further impaired in small firms due to this problem. Just over one-half of the FJC employees in the smallest public and private firms failed to achieve equity due to lack of a male comparator. These statistics may actually understate the gap between large and small firms. The surveys of public and large private firms were conducted before the introduction of proportionate value and proxy comparisons (to help solve this problem) in 1993. For example, larger firms possess the administrative pay systems and large samples of employees necessary to implement proportionate value comparisons and make them meaningful. ${ }^{20}$

The review of the legislation commissioned by the PEO in 1996 (Read 1996) provides interesting anecdotal evidence about compliance. Through consultation Read reports learning of "extensive non-compliance among small to medium size employers" (p. 4). A survey of 4800 members of the Canadian Federation of Independent Business (an organization of small to medium size businesses) submitted to the review, reveals that just 20 percent of employers covered by the Act had completed any of the required steps (Read 1996, p.38). ${ }^{21}$ The reasons for non-compliance included "lack of time and money" and the "requirements

${ }^{19}$ For example, 37 percent of 100-499 employee firms who had done some work on pay equity report purchasing a new job comparison system compared to just 2 percent of 10-49 employee firms who had posted some plans.

${ }^{20}$ The surveys also report other information such as estimates of administrative costs per employee that are difficult to interpret due to non-response and differences in the way the questions were asked across surveys.

${ }^{21}$ Consistent with the evidence reviewed above, however, the survey also reveals that compliance was positively correlated with firm size. 
are too complicated/difficult". This level of compliance is consistent with the results from the survey of 10-49 employee firms.

A final source of information is the commentary of pay equity advocates and critics over the period. A review of pay equity practitioners in trade unions laments that the Ontario legislation restricts comparisons and negotiations over pay equity plans within establishments (Genge 1994). It favorably cites public sector applications of comparable worth in other provinces where central bargaining is the norm. In an attempt to reduce the number of female jobs with no male comparator, the PEO proposed "external average adjustment": female job classes in the private sector lacking male comparators would receive the average pay equity adjustment within their industry. Finally, free collective bargaining could also lead to complications: once pay equity is achieved the legislation permits gender wage differentials to re-emerge if they result from differences in power across bargaining units. Robb (1990) argues that this provision in tandem with gender differences in union membership could serve to widen the male-female wage gap.

A common thread here is that the Act's accommodation of a decentralized labor market was an obstacle to compliance. First, gender segregation by establishment limited the comparison of male and female jobs. The suggested solution was to widen the definition of an establishment and allow local or province wide bargaining in union environments. Second, free bargaining between unions and employers was viewed as potentially undermining pay equity. Third, the exceptions for compensation differences based on productivity related attributes were viewed as an escape hatch for employers. Robb (1990, p.18) identified the tension here: "Clearly, allowing such exceptions is a double-edged sword. While many of these provisions are essential if the labor market is to be allowed to operate efficiently, it is also recognized that they can be used by employers to circumvent the legislation". Finally, pay equity was enacted as a mostly self-managed program, consistent with the operation of many other labor market regulations in North America. More stringent reporting obligations and monitoring may have led to higher rates of compliance but would also entail higher administrative costs. As Bergmann (1989) (p. 58) observes, this alternative is likely to be "expensive, unwieldy and unnecessarily intrusive".

The evidence, therefore, is that there were substantial problems with compliance and 
implementation of the law, especially in small firms. Although seldom acknowledged in discussions of pay equity, or in simulations of its effects, this, perhaps, is not surprising. The reasons are likely the same as those that exempted firms with less than 10 employees from the legislation in the first place. Pay equity comparisons work best in large samples. Small firms are more likely to have trouble finding male comparators, and wage line methods would seem to pre-suppose some minimum number of observations. The job evaluation systems necessary to carry out comparable worth evaluations can be expensive, and are less burdensome when they can be amortized over a large number of employees. Finally, the underlying principle of comparable worth, of making disparate jobs commensurate, is perhaps better suited to academic debate, or the administrative compensation systems of large firms, than to the daily life of the small employer. These issues may become even more important in the future as firms adopt non-traditional job design, such as self-directed work teams and non-standard employment, in the context of labor market restructuring (see Piore (1986)).

\section{What Are the Effects of Comparable Worth Policies on a Decentralized Labor Market?}

\subsection{The Potential Impacts of Comparable Worth}

Proponents of comparable worth argue that the impact of the law should be a straightforward increase in wages in female jobs, and therefore a reduction in the gender wage gap. Economic models of the labor market yield quite different predictions. Killingsworth (1987) explores the effects of a pay equity policy in a two sector model of low wage female jobs and high wage male jobs. Comparable worth prescribes wages in female jobs above the equilibrium level. Moving up along the demand curve in the low wage sector entails a decrease in employment. The direct effect, therefore, is similar to the predicted impact of minimum wages or unionization, or more generally any intervention that raises the wage above the level indicated by the intersection of supply and demand in the relevant market.

The increase in the wages of female jobs leads to substitution and scale effects. Since female and male jobs are typically defined along occupational lines the elasticity of substi- 
tution between the two job classes is arguably small. This increases the likelihood that the the negative scale effect for male jobs outweighs any positive substitution effect, leading to a decline in demand in the high wage sector.

The initial distribution of the sexes across the two job types in this model is due to a taste for discrimination among employers of high wage jobs. Their psychic income from employing males is an increasing, concave function of the male wage bill. A decline in demand for these jobs reduces the wage bill, and thus increases the amount they "discount" male wages. Therefore, the negative scale effect increases the male/female wage differential within this sector; at least in the short run in which the supply of males and females to the two sectors are fixed.

In the longer run, the destination of individuals released from the female jobs can be important. Their subsequent movement into jobs that are not covered by the legislation will be attenuated by the re-training and qualification requirements of cross-occupational migration. In the present context an obvious destination is smaller firms where the law was largely ignored. There will be fewer impediments to this within-occupation movement, and it will allow individuals to preserve any occupational specific capital. The analogy is to a two-sector model of minimum wages or unions with covered and uncovered sectors. The migration of workers results in an outward shift in the supply of labor to this sector, that will depress the wages of female jobs in smaller firms.

The net effect of the law on female wages at the aggregate level is therefore ambiguous, reflecting the countervailing impacts on wages in firms that do and do not comply. The release of workers into the "uncovered" sector will be attenuated if some individuals decide to queue for the now higher paying female jobs in complying firms. In the much longer run, the supply of workers to these jobs may be further augmented by individuals in other occupations attracted to these female jobs by the higher wages.

In Killingsworth's model the initial increase in wages in female jobs, following the implementation of comparable worth, is given exogenously. In application, comparable worth policies tie the wages in female jobs to those in male jobs. This additional constraint on the firm's hiring decision would lead to a trade off between the cost and (possibly unobserved) skills of individuals filling male jobs. Empirically, this would turn up as a 
decline in the wages in male jobs as lower skilled candidates were hired.

Another issue not captured in this model is that male/female job comparisons may affect employee morale and productivity. Akerlof and Kranton (forthcoming) provide a framework to consider these effects in their analysis of "economics and identity". They cite examples of men in male jobs, such as coal handling, finding their masculinity threatened by the presence of female co-workers and relieving "their anxiety by taking action against women co-workers" (p. 21). ${ }^{22}$ Similar resentment could be generated by comparable worth comparisons that argue that these jobs are equal to traditionally female jobs. The result is increased taste discrimination against women in male jobs by co-workers and, in turn, by employers. Less dramatically, male resentment may manifest itself as a lack of cooperation and less informal training of female co-workers. This would reduce the productivity and hence the wages of women in these male job classes. Empirically, we search for these sorts of "backlash" effects by focusing on "blue collar" work as a proxy for traditional male jobs.

\subsection{Data and Empirical Strategy}

The data for our empirical analysis are drawn from the Canadian Labor Force Survey (LFS), which is a monthly study of individuals' labor force status. At the end of the 1980's supplements, called the Labor Market Activity Survey (LMAS), were conducted collecting information on wages, union status, number of employees in the workplace (among other variables) for a subset of individuals in the LFS. In January 1997, these questions were made part of the monthly LFS. We combine data from two different waves of the LMAS, the years 1987 and 1988, and from the 1997 and 1998 LFS. The two-year periods 1987/88 and 1997/98 nicely bracket the introduction of the comparable worth legislation in Ontario.

The LMAS is a retrospective survey covering year-round labor market activity. To mimic a point-in-time survey, we select job information as of the third week of November in each year. Similarly, we use the November rotation of the 1997 and 1998 LFS. We sample all individuals who are 16-69 years of age. Wages are obtained from the main job at this time; they are the actual hourly wage for workers paid by the hour and the usual

${ }^{22}$ Akerlof and Kranton (forthcoming) also cite the work of Padavic (1991) for more detail. 
hourly earnings for other workers. ${ }^{23}$

These data do not include information on the femaleness of a particular individual's job. We therefore identify individuals "at risk" of receiving a pay equity award by merging information on the percentage of 4-digit occupational (1980 SOC) employment that is female (PFEM) obtained from the 1991 Canadian Census using the occupation codes available in both data sets. ${ }^{24}$ We therefore attribute to individuals, both in $1987 / 88$ and in $1997 / 98$, the proportion of employment in their occupation that is female computed at the provincial level from the 1991 Census. We then use this variable to determine whether a sample member works in a female, integrated or male job according to the definitions in the Ontario legislation. ${ }^{25}$

Our empirical strategy is to compare changes in different measures of wages and employment in Ontario before and after the law was implemented to changes in these variables in a control jurisdiction. To effectively difference out other changes in the economic environment and were co-incident with the implementation of the law, the control jurisdiction must be a good match for Ontario in all dimensions except the evolution of pay equity legislation. Our initial choice is workers in the province of Quebec. This adjacent province is most comparable to Ontario in both population and economic activity.

During the period we examine, Quebec's pay equity provisions were contained in its

${ }^{23}$ Hourly wages are in 1997 dollars. In our analysis of wage data, we include all wage and salary workers who are not full-time students and are earning more than $\$ 1.00$ an hour. We exclude full-time students because they are excluded from the legislation, when they work in connection to their studies. We are able to compute the wage similarly in the before and after period.

${ }^{24}$ The 1980 standard occupation codes comprise approximately 500 categories. In the 1996 Census, occupational coding followed a totally different classification system, the 1990 NOC, which is not compatible with the previous system. The number of observations in our provincial sub-samples of the 1987/88 LMAS and 1997/98 LFS are too limited to provide reliable estimates of the percentage female by occupation at the 4 -digit level. Even in the 20 percent extract of the Census we use, there are some occupations that are not represented in each province.

${ }^{25}$ Our analysis abstracts from any changes in percentage female, and therefore job type, endogenous to the law. We have examined changes in the percent female by major (2-digit) occupational groups using our LMAS87/88 and LFS97/98 data. While some occupations become more female (e.g., managerial, administrative and related occupations) and others less (e.g., clerical occupations) over the period, there were no changes in the job type - female, integrated or male - among the major occupational groups, with the exception of artistic, literary occupations that, in Ontario, changed from female in $1987 / 88$ to integrated in $1997 / 98$. 
human rights code. ${ }^{26}$ The resulting system was complaint based and in principle covered all workers outside the federal jurisdiction. Enforcement was the responsibility of the Quebec Human Rights Commission. Despite the seemingly wide-ranging jurisdiction of these provisions, Weiner and Gunderson (1990) report that the legislation was rarely used. Likewise, Cihon (1988) reports that in the period preceding 1984 there were 77 complaints, 28 of which were either dismissed or ultimately withdrawn. ${ }^{27}$ Complaints in the period 1982-1986 were even less frequent. Cihon argues that the provisions were not well publicized by the Human Rights Commission in this period, due to the limited resources available for their enforcement. ${ }^{28}$ Quebec has recently (1996) enacted pay equity legislation with many similarities to the Ontario Act, but the first awards are not due until 2001, which falls outside our period of analysis. Therefore, in the period of interest the existing comparable worth provisions in Quebec were little used, and there were no significant, new initiatives in the period.

Some average characteristics of individuals in the two provinces are provided in Table 4 . The statistics reveal many similarities. That said, an important difference is the higher unionization rate (of approximately 10 points) in the province of Quebec. Another interesting Ontario/Quebec difference is the greater growth of educational attainment in Quebec, as measured by the incidence of a university degree. ${ }^{29}$ Finally, the distribution of employment by firm size reveals how devastating the problems of compliance and implementation in small firms, documented in Section 2, were for the overall impact of the law. Roughly two-thirds of Ontario's females and nearly 60 percent of Ontario's males work in establishments of less than 100 employees.

Our empirical investigation begins with the base specification, for individual $i$,

$$
y_{i t}=\alpha_{T} T_{i t}+\alpha_{O} O N_{i t}+\alpha_{T O} T_{i} \cdot O N_{i t}+X_{i t} \beta+\varepsilon_{i t},
$$

\footnotetext{
${ }^{26}$ The concept of pay equity was introduced to the code in 1977.

${ }^{27}$ Successful claims resulted in settlements, which affected approximately 3500 workers.

${ }^{28}$ Symes (1990) argues that the disappointing results of enshrining pay equity provisions in the human rights codes of Quebec and the federal government (in 1978), were a prime motivation for lobby groups to seek pro-active legislation.

${ }^{29}$ While the education classes between the two periods considered are not fully comparable, 'university degree' is an exception.
} 
where $T_{i t}=1$ for observations from 1997 or 1998 and 0 otherwise, $O N_{i t}=1$ if the individual $i$ lives in Ontario and 0 otherwise, the $X_{i t}$ are controls for demographic and job/firm characteristics, and $y_{i t}$ is the logarithm of the wage or a measure of employment in a particular class of jobs. The primary coefficient of interest is $\alpha_{T O}$ on the first order interaction $T_{i} \cdot O N_{i}$. This provides an estimate of the difference in the change in $y_{i t}$ in Ontario and Quebec between 1987/88 and 1997/98, conditioning on the control variables: a quartic in age, six education classes, dummies for metropolitan area, industry(10), employment in the federal, provincial, and local public service, part time work, married, visible minority, tenure, union status, and firm size (4), where appropriate.

We start by estimating (1) (by weighted least-squares using survey weights) separately, by sex, for individuals in female jobs, male jobs and integrated jobs, respectively. The preceding discussion, however, revealed important lapses in compliance in some firms. Therefore, one way of more carefully isolating the impact of the legislation is to focus on workers in those firms where compliance was most complete. For example, we can focus on non-unionized workers in large firms. Because public sector workers are largely unionized in Canada, this also focuses on private sector applications. ${ }^{30}$

Incomplete compliance can also be used to address a potential flaw in our identification strategy: the presence of province specific labor market trends and/or shocks. If these are important, workers in Quebec will not provide the appropriate counterfactual. If we assume that the legislation was of no effect in small firms, we can use the experience of their workers to control for these shocks. As noted above, firms with less that 10 employees were exempt from the legislation. Any direct effect of the law on firms with 10-49 or 50-99 employees was clearly compromised by lapses in compliance.

A further consideration, however, is that any disemployment effects of the law in larger firms, could cause spillovers of workers into smaller firms thereby depressing wages there. These would be most severe if the disemployment effects were large and the resulting

${ }^{30}$ While U.S. datasets typically include a variable called "class of worker" that identifies public and private sector workers, a similar variable is not available in our Canadian datasets. Our analysis of private vs. public sector is thus limited to proxy analysis. For example, we performed some analysis excluding public administration workers and found that it did not change our results. 
mobility was primarily within occupation. In this case, our estimate of the direct effect of the legislation on the wages in female jobs will be biased upwards as it will also include the indirect negative effect on wages in female jobs in firms that did not comply with the legislation. Attenuating this bias will be any (greater) ability of large firms to absorb the increased wage costs mandated by the legislation due to, for example, more dominant market positions and the associated rents.

To implement this strategy we estimate the equation

$$
\begin{gathered}
y_{i t}=\alpha_{T} T_{i t}+\alpha_{O} O N_{i t}+\alpha_{L} L_{i t}+\alpha_{T O} \cdot T_{i t} \cdot O N_{i t}+\alpha_{T L} \cdot T_{i t} \cdot L_{i t}+ \\
+\alpha_{O L} \cdot O N_{i t} \cdot L_{i t}+\alpha_{T O L} \cdot T_{i t} \cdot O N_{i t} \cdot L_{i t}+X_{i t} \beta+\epsilon_{i t}
\end{gathered}
$$

where $T_{i t}$ and $O N_{i t}$ are defined above, and, where $L_{i t}=1$ for workers employed in a sector assumed to be affected by the law and 0 otherwise. The coefficient of interest, $\alpha_{T O L}$, indicates the relative change in the Ontario/Quebec difference in the $y_{i t}$ differential between workers for which the legislation is assumed to have had some effect and those for which it did not.

A remaining issue is whether, conditional on compliance, there was anything for the comparable worth law to remedy. In Figure 1 and Table 5 we document the gender wage gap in Ontario over the period. Figure 1 contains kernel density estimates of female and male wages in Ontario by job type in 1987/88 and in 1997/98 superimposing the female and male densities. Note that the distribution of female wages in each case lies to the left of the distribution of males wages. While we do not condition on any observables, it is clear by this metric that women are lower paid whichever the job type.

In Table 5 we report mean wages for women and men, as well as the female/male wage ratio for all jobs and by job types, for Ontario and Quebec in 1987/88 and in 1997/98. The time difference for location represents the relative wage or gap growth in Ontario versus Quebec. The numbers show that the increase in mean wages for all jobs was slightly higher in Ontario than in Quebec for both women and men. For Ontario women, changes in mean wages in integrated jobs were slightly higher, while changes in male jobs lagged. For Ontario men, the growth of wages in integrated jobs were again slightly higher, while growth in female jobs trailed. A difference-in-difference calculation reveals that the decrease in 
the overall gender wage ratio was not greater in Ontario than in Quebec over the period. Differences begin to emerge, however, when we consider the gender gap change by job type. In Ontario greater progress was made in female jobs, while in Quebec greater progress was made in male jobs. The mechanics of pay equity link the wages in female jobs to the wages in male jobs. Therefore, another gender gap addressed by the policy is the ratio of average wages in female jobs to average wages in males jobs. In the last line of Table 5 we report the ratio of average female wages in female jobs to average male wages in male jobs. By this measure, Ontario's performance was marginally worse than Quebec's.

Some previous studies report that at the aggregate level Canadian women do not face much of a penalty to work in female jobs, although there is an substantial penalty for males (Baker and Fortin (1999), Baker and Fortin (forthcoming)). We provide an initial description of the relationship between wages and occupational gender composition in Figure 2, where we plot kernel regressions of average occupational log wages on PFEM, weighting by occupation size. ${ }^{31}$ The vertical line denotes the level of PFEM, 0.6, at which the job classification switches from integrated to female. For all levels of femaleness rates, there are large gender gaps evidenced by the distance between the men's and the women's regression lines for the corresponding years. ${ }^{32}$ Any difference in the reduction in this gap over the period gives a visual impression of the potentially different impacts of the law at the various femaleness rates. For example, for any impacts on clerical workers, the focus should be on very high $(P F E M>0.95)$ femaleness rates.

We refine this inference in Table 6 reporting the estimated (linear) effect of occupational gender composition on women's and men's log hourly wages in both provinces. These estimates are from a two-step procedure in which we first regress log hourly wages on the indicated socio-demographic controls and occupation fixed effects. The estimated fixed effects are then regressed on PFEM, weighting by the sum of the individual level LMAS or LFS supplied weights by occupation. ${ }^{33}$ At the aggregate level the estimates for both males and females are sometimes insignificant, and many are smaller than the estimates

${ }^{31}$ We use a Gaussian weighing function and a bandwidth of 0.075 for both provinces.

${ }^{32}$ This result is consistent with new evidence by (Bayard, Hellerstein, Neumark and Troske 1999) that there is a sizeable within-occupation/establishment gender gap.

${ }^{33}$ See Baker and Fortin (forthcoming) for a complete description of the procedure. 
that are typically retrieved from U.S. data. There is a fair amount of heterogeneity by sector, however. For example, in both provinces the estimated penalty is larger in the nonunion sector than the union sector. The effect on female wages in Ontario's union sector is actually positive and statistically significant. The point estimates by establishment size indicate that the penalty is generally greater in smaller firms than in larger establishments, at least for females. This suggests that the target for the law was largest in establishments where the law was largely ignored. The results for large establishments, however, reflect the counterbalancing influences of the penalties in the union and non-union sectors. Focusing on non-unionized workers in larger establishments reveals a more substantial penalty to female jobs. For females in Ontario, the penalties were -0.202 (0.066) in 1987/88 and -0.197 (0.060) in 1997/98. Therefore, there was quite a substantial target in the firms where compliance was the highest. It is also interesting to note that these estimates are very similar to estimates of the penalty to female jobs in the United States over this period (Macpherson and Hirsch 1995).

\subsection{Results}

An overview of the period in which the Ontario law came into effect is provided in Figures 3 and 4. In Figure 3 we plot the average real log hourly wages of women and men in Ontario and Quebec between 1985 to 1996 using data from the Survey of Consumer Finances. ${ }^{34}$ We also plot the implied linear trends before and after 1990, the first year in which the law might be expected to have some impact. Despite the severe 1990 recession, the wages of women continue to grow in the 1990s. In contrast, the wages of men start on a downward trend in this period. In either period men and women in Ontario earn more on average than their counterparts in Quebec.

In Figure 4, we plot the employment rates of women and men in the two provinces (the

${ }^{34}$ The Survey of Consumer Finances is comparable to the CPS March supplements. The reported statistics are the logarithm of the ratio of annual earnings in reference year to annual hours defined by the product of weeks worked in the reference year and hours worked in the reference week. Therefore, only individuals who worked both in the reference year and reference week are included in the samples for the calculations. Nominal wages were converted to 1997 dollars using the Consumer Price Index. 
solid lines for Ontario and the dashed lines for Quebec). ${ }^{35}$ Consistent with the stylized facts, in the earlier period women's employment rates, fueled by the higher labor market participation of young women, show a positive trend. ${ }^{36}$ Following the severe recession of 1990/92, many groups exhibit negative employment growth rates in the $1990 \mathrm{~s}$. The trend in women's employment rates in Ontario after the law is however, the only one which is statistically significantly negative. ${ }^{37}$ This is in contrast to Quebec where women's employment rates stabilize in the 1990s. For men, employment rates after the law display similar trends in both provinces.

In table 7 we report estimates of equation (1) using hourly wages as the dependent variable. In the first row we report estimates of $\alpha_{T O}$, by sex, for all workers and by job type. The results for all jobs indicate that between 1987/88 and 1997/98 the wage growth of both men and women in Ontario was about a 5 percent higher than their counterparts in Quebec. The results by job type in the next columns indicate this advantage was widespread. This common advantage suggests the presence of a province specific trend.

In the next four rows we break down this inference by firm size and union status. Distinguishing the workers by firm size is motivated by the evidence on compliance. Distinguishing the workers by union membership is motivated both by the information on compliance and the evidence that female jobs in Ontario's union sector were already relatively well paid. These estimates do reveal relatively higher wage growth among non-unionized women in female jobs at large firms, although not for their male counterparts. Note, however, that if we were to attribute this effect to the legislation, we would also conclude that the pay equity law benefited workers in integrated jobs at large non-union firms. This is not impossible: some integrated jobs at the 4-digit occupational level may be female jobs at the firm level, and therefore our integrated category contains some female jobs. ${ }^{38}$ However,

${ }^{35}$ Again we use data from the Survey of Consumer Finances. The reported statistics are employment rates in the reference week for individuals 16-69.

${ }^{36}$ As female labor market participation reaches an "upper bound", the upward trend may begin to abate as it did in the 1990s in the United States.

${ }^{37}$ Regressing the employment rates on a constant plus a time trend gives a coefficient of $0.0048(0.0020)$ for Ontario women and of -0.0020 (0.0035) for Ontario men. Admittedly, these coefficients are not statistically different.

${ }^{38}$ Another possibility emerging from the firms' experience is that pay equity plans promoted 
given that the estimated effect for integrated jobs is larger than the estimated effect for female jobs, we would need to assume that our integrated category is dominated by female jobs at the firm level that received the largest pay equity awards.

More generally, these disaggregate results provide further confirmation of the common advantage of Ontario's workers. One exception, however, is non-unionized women in male jobs at large firms. They experienced a roughly 17 percent relative decrease in wages over the ten year period, while their female counterparts in male jobs at the other firms experienced a roughly 9 percent relative increase.

To address the evidence of a Ontario specific effect, in Table 8 we present estimates of equation (2). Drawing on the evidence from section 1, we assume that small firms in Ontario were untreated by the pay equity law due to their lack of compliance, and the greater difficulties finding male comparators. We assume workers in establishments with up to 99 workers to be "untreated" by the law, while those at establishments of $100+$ employees to be "treated". The pattern of the results is not greatly affected if we define untreated firms as those with less than 20 employees, deleting those with 20 to 99 employees from the analysis. ${ }^{39}$ Recall that firms with less than 10 employees were exempt from the legislation.

The results are reported in the first panel of Table 8 . For all female workers, this differencing strategy eliminates any Ontario specific advantage across all jobs. Breaking the result down by job type, we see that women in larger establishments in female and integrated jobs did no better than their counterparts in Quebec. Therefore, once we account for province specific trends there is little evidence that the pay equity law increased women's wages in female jobs in Ontario. Formalizing the inference from Table 7, however, we obtain further confirmation that the relative wages of women in male jobs in Ontario fell. Over the 10 year period, the 15 percent decline in female wages in males jobs at large firms in Ontario is the primary contributor to the decline in females' wages at the aggregate level. For men there is still evidence of an Ontario specific advantage that is driven by workers in

the use of administrative pay system for all types of jobs.

${ }^{39}$ The standard errors, however, are correspondingly larger. See the estimates in appendix table A-1. 
male jobs. These workers gained just over 5 percent relative to their Quebec counterparts.

In the next two rows these results are broken down by union status. For women of either status there is no evidence of an advantage to workers in female jobs from the legislation. The new result here is that the negative effect on wages in male jobs is primarily among non-union workers. Here the estimated relative 10 -year deficit in wages is sizable at just over 30 percent, although the standard error is also larger. The new inference in the results for men is that non-union workers in female jobs also appear to have suffered a relative wage loss, although the estimate is much smaller than the result for non-unionized women in male jobs and the standard error is large. Also, this inference must be viewed through the lens of the relatively higher wage growth observed for men in integrated and male jobs in Ontario which we attribute to a province specific effect.

In the next two rows (rows 4 and 5), we provide evidence of further heterogeneity in the results among non-union workers in larger establishments. Searching for the backlash effects of Akerlof and Kranton (forthcoming), we break down the results by white/blue collar jobs. ${ }^{40}$ For women, the estimates indicate that the negative effect on wages in male jobs is primarily a blue collar phenomenon. The point estimate also suggests some advantage to blue collar workers in female jobs, although this is also observed in integrated jobs. For men, the negative wage effect in female jobs also appears to be a blue collar effect, but the standard error is very large and there are still signs of province specific effects in the estimates for the other job types.

Given the information on compliance and the implementation of the Act, we have access to another identification strategy. We can simply use larger/smaller establishment differences in Ontario, dropping the Quebec data. A justification for this approach would be that province specific effects are more important than firm size or sector specific effects that the cross province strategy addresses. A corresponding set of results using only the Ontario data is provided in rows 6 through 10 . The pattern of the results is generally

${ }^{40}$ White collar jobs are those whose 4-digit code is below 5000 (complete list of occupational codes and percentage female available from the authors on request); they include managerial, professional, technical and clerical jobs. Blue collar jobs are those with a 4-digit code of 5000 and higher; they include sales, service, farming, fishing, forestry, mining, processing, machining, product fabricating, construction, transportation and craft jobs. 
similar, although the magnitude of the estimates differ in some cases. For women there is little evidence of a relative increase in the wages in female jobs. Where we do obtain a positive estimate for these jobs it is accompanied by a positive estimate for integrated jobs. We also obtain a negative estimate for women in male (primarily blue collar) jobs. One difference here is the effect also turns up in the union sector. For men the negative estimate in female jobs shows up more consistently, although it is still primarily a blue collar effect. There is also more consistent evidence that we are differencing out any effect in integrated jobs, with the exception of the estimates for blue collar workers.

We have tried other splits of the data to explore the sensitivity of this inference. Commentators on the Ontario legislation such as Read (1996) provide specific examples of pay equity awards to female jobs. Why, then, is there no evidence of relative growth in the wages of female jobs in Ontario? Of course any increases in wages resulting from specific awards could have come at the cost of lower wage growth from other sources, or have been counterbalanced by lower wage growth in subsequent years. The law prescribes no reductions in wages to achieve pay equity, but (of course) can say little about wage growth over a period of the length we examine. We have re-estimated equations (1) and (2) adding a dummy variable for a) clerical workers or b) very female jobs (PFEM $\geq 0.9)$ along with a full set of interactions. The first specification is motivated by the evidence from the firm surveys that clerical workers were most likely to receive awards, while the second is an attempt to focus on workers most likely to be in female jobs at the firm level. In either case (estimates not reported and available on request) we find little consistent evidence of relative growth in female jobs of these types in Ontario. ${ }^{41}$ The estimates switch signs across specifications and are largely insignificant.

How do these changes in wages map into changes in the male/female wage gap? In Table 9 we report estimates of equation (1) pooling men and women, and adding a dummy variable for gender, along with a full set of interactions with $O N_{i t}$ and $T_{i t}$. The overall effect on the law on the aggregate gender wage gap is given by the gender, Ontario, year

${ }^{41}$ Note also that over the period considered, clerical work declined from 32 percent of the Ontario female workforce in 1987/88 to 24 percent in 1997/98, which would reduce any aggregate effect of increases in the wages of clerical workers. A similar decline has been observed in the United States, and may be related to technological change. 
interaction in the second column of the first row. There is no statistically significant relative change in the aggregate wage differential in Ontario. Reference to table 7 reveals that the almost equal relative advantage of both men and women in Ontario over the period lies behind this result. A similar conclusion, with a similar rationale, is found in the estimates by job type in the succeeding entries of the row.

In rows 2 through 4 we focus on workers at establishments that complied with the law. Consistent with the inference from table 7, among non-unionized workers at larger establishments we find relative decreases in the gender wage gap in female jobs and relative increases in the gender wage gap in male jobs. The former is a result of the relative decrease in the wages of Ontario men working in female jobs while the latter is due to the relative decrease in the wages of Ontario women working in male jobs. The results in rows 5 and 6 provide further confirmation of this inference, adding in the additional control of smaller establishments in Ontario. Therefore, in the complying firms any relative gain in the stature of women - in female jobs - came through the negative effect on the wages of men, while there was a relative deterioration in the status of women in male jobs. More generally there is no evidence here that Ontario's extension of pay equity to the private sector had an aggregate effect on the relative compensation of women.

One way to determine the employment effects of the legislation is to examine the flows of workers out of female jobs over the period the law came into effect, using the experiences of other provinces or other types of jobs as a control. This sort of analysis is not possible with the cross-section data we use here, and panel data spanning the period is not available. Examining the overall employment rates of men and women is not necessarily appropriate, as individuals released from now higher paying female jobs may find employment in other types of jobs where markets clear, or in the uncovered sector.

What we examine here is the share of employment in female jobs. One reason this might decline in response to comparable worth legislation for a given gender is purely administrative. Firms may alter their hiring practices to integrate jobs and thus remove them from the purview of the law. Any general reductions in the share of employment for both men and women would result from the disemployment effects of pay equity awards to female jobs dominating the net substitution and scale effects on other types of jobs. 
In the first panel of table 9 we report estimates of equation (1) using a dummy variable for working in female jobs as the dependent variable, for workers in large and small establishments respectively. For women, the estimate for all workers in larger establishments is negative but not significant. Breaking this down by union status shows that the effect among union workers drives the aggregate result. In smaller establishments the share of female jobs increases uniformly in the two sectors. For males, there is little to distinguish the estimates for the larger and smaller establishments. The share of female jobs in either case displays no substantive change. In the second panel are the estimates using the identification strategy of equation (2). Both estimates using small firms as an additional control group indicate small reductions in the share of employment in female jobs for women. For men, the estimates are consistently small and statistically insignificant.

Put together, the results of both panels indicate that there might have been a shift in women's employment in female jobs from larger establishments, the covered establishment to the smaller ones, the uncovered ones. More generally though, the inference is that the impact of pay equity awards on employment in female jobs were very small from the perspective of a 10 year period.

\subsection{Interpretation}

The preceding analysis indicates that Ontario's comparable worth act had little positive effect on the overall stature of women in the province. There is no economically or statistically significant difference between the trends in the gender wage gap in Ontario and Quebec over the period. We are also unable to uncover any robust evidence of a positive effect of the law on the wages in female jobs. In those cases where we do find relatively higher wage growth in female jobs in Ontario, we also find relatively higher wage growth in integrated jobs which were not directly affected by the legislation. We attribute this coincidence to an Ontario specific trend. In specifications that attempt to accommodate these effects, the wage growth for women in female jobs in Ontario and Quebec is very similar.

The primary factors contributing to the aggregate impotence of the law were the lapses in compliance and the problems with implementation in small firms. The Ontario experi- 
ence provides important new evidence that the design and implementation of comparable worth law for the private sector of a decentralized economy is not a straightforward extension of what may work in applications to the public sector. The practice of comparing male and female jobs would appear to demand resources and pools of employees that exceed those of most small employers. This proved to be a severe limitation. Only 33 percent of working women and 5 percent of working men are employed in female jobs at large firms where compliance was relatively complete.

Commentators allude to possible manipulation of the design of pay equity programs by employers. While we have no direct evidence of this, it is important to note that the latitude granted to employers under the Act is consistent with maintaining a well functioning decentralized labor market. Simply put, many critics pointed out that the law would work better and could be more easily monitored if the labor market were more centralized. ${ }^{42}$ Other factors that may contribute to our failure to find an aggregate impact of the law include the small, negative effect of gender composition on female wages in some sectors of the labor market, possible spillover effects on untreated sectors and negative effects on women in male jobs.

When we focus on larger firms, however, to try to more effectively isolate the impact of the legislation, we remain hard pressed to find a lasting advantage to women in female jobs. Our most consistently estimated effect is that women in male jobs would appear to have been hurt by the legislation, by some estimates quite substantially. Men in female jobs would also appear to have lost some of the advantage they previously enjoyed. As a consequence we observe a relative decrease in the gender wage differential in female jobs and a relative increase in the differential in male jobs. This inference is certainly not that expected by proponents of pay equity, although the latter is a prediction of Killingsworth (1987). It is also at odds with previous studies of pay equity in state and local governments or in Australia (but see Killingsworth 1990).

One account of these results is composition effects. As noted above, comparable worth

${ }^{42}$ Coincidently, if this advice were followed then it would also address the problem of addressing wage differences between male and female jobs across firms, as emphasized by Johnson and Solon (1986). 
policies tie the wages of male and female jobs. Once equity is achieved, the legislation explicitly forbids any actions that raise the wage differential between these jobs. This puts an extra constraint on firms' hiring decisions, and could lead to a trade off between the cost and skills of individuals filling male jobs. Why then would this affect women in male jobs but not men in male jobs (as our results suggest)? Here again the provisions of the legislation can be instructive. It directs employers to compare female jobs to the lowest paid comparable male job class. That is, the wages in female jobs are tied to the wages in the lowest paid comparable male job. Who holds these lower paid male jobs? The information in Figure 1 and Table 5 reveals that females are more likely to hold the lower paying jobs. That said, any changes in observable characteristics are directly controlled for in the estimation. Unfortunately we have no credible approach to holding unobservables constant in the comparisons, which are acknowledged as a major determinant of earnings. ${ }^{43}$

Another possibility is changes in the composition of occupations within the different job types, as employers attempt to "integrate" jobs. In table 11 we present estimates of equation (2) reweighting the 1997/98 data to match the distribution of occupations in $1987 / 88 .^{44}$ The results in row 1 should be compared to the results in row 1 of table 7 . Focusing on firms where there was higher levels of compliance, rows 2 through 5 of table 11 should be compared to rows $3,5,8$ and 10 of table 8 . For women, the re-weighting has almost no effect on the estimates. For men we do observe a reduction in the (absolute value of the) estimates for female jobs (rows 1, 2 and 4 of table 10) that is consistent with the integration story. The estimated relative wage growth in female (in fact all) jobs is now greater, although the standard errors are large. The results for blue collar workers, however, change very little or are larger after re-weighting.

Alternative accounts of the results are not directly testable in our data. The legislation tied the wages in female and low wage male jobs perhaps leading to a decline in the unobservable skills of individuals who filled them. Bergmann (1989) argues that complying

\footnotetext{
${ }^{43}$ Here we refer to the fact that the R-squared from the estimation of a human capital model of earnings is typically quite small.

${ }^{44}$ Here predicted probabilities belonging to either time period are obtained from a linear probability model where the only explanatory variables are the occupation dummies, which is equivalent to reweighting with the ratio of the proportions of the workforce in occupation in each time period.
} 
firms must offer lower wages in male jobs to offset the pay equity awards to female jobs and maintain a competitive total wage bill. The fact that the negative effect for females in male jobs is concentrated in blue collar work may indicate the sort of backlash effects suggested by Akerlof and Kranton (forthcoming). The negative effects for males in female jobs may be due to the fact that comparable worth evaluations led to greater uniformity in wages by job class. Whatever the source, unexpected allocations of the rewards and penalties of comparable worth legislation (as observed here) have precedence (Orazem and Mattila (1990)).

\section{Conclusions}

We empirically investigate the introduction of comparable worth to the Ontario labor market in the early 1990s. This was a comprehensive, pro-active, initiative that applied to public sector employers and private sector employers of 10 or more employees.

Our first finding is of substantial lapses in compliance with and implementation of the law in small firms. These employers appear to have lacked the resources to construct the necessary job evaluation programs, well-delineated job classification systems, and sufficient samples of male and female jobs to make meaningful comparisons. As a consequence, the policy had little effect in a sector of the labor market that employs roughly 65 percent of working females and nearly 60 percent of working males. While some of these problems may be peculiar to Ontario, there are more general lessons for applications of comparable worth to the private sector. This is certainly the reading of critics of the Ontario experience. Their prescriptions, however, are largely for the labor market rather than for the legislation. The decentralized nature of the Ontario labor market, the proliferation of small firms, the prevalence of free collective bargaining, all appear to have worked against the policy. The suggested antidote was inter-firm job comparisons and pay equity awards, centralized collective bargaining, centralized enforcement and monitoring of the pay equity plans.

Our second finding follows almost trivially from the first. Because much of the Ontario labor force was untreated by the law, we find no robust evidence that the pay equity legislation transferred a general benefit to women in Ontario over a six to eight year period. 
Any relative increases in wages in Ontario over the period were enjoyed in all types of jobs: female, integrated and male. Furthermore, at the aggregate level the gender wage gap closed at a similar rate in Ontario and Quebec. Likewise, the penalty to female jobs in both provinces grew by comparable amounts since the law was introduced.

Our third finding flows from an analysis of those sectors where compliance was relatively complete. Any direct, positive effects on the wages of females working in female jobs are modest and typically statistically insignificant. The pay equity awards documented in reports from the Pay Equity Office do not appear to have had a lasting effect. Our most consistently estimated effect is suppressed wage growth: for women working in male, especially in blue collar, jobs, and to a lesser extent males working in female jobs.

The lessons from this investigation are at least two-fold. First, comparable worth would appear to be a unwieldy and complicated regulation for a decentralized labor market. The logistics of implementing comparable worth in the private sector has not been closely examined in previous studies. There would appear to be substantial obstacles to the effectiveness of this policy in small firms where the majority of men and women are employed. Furthermore, suggested improvements to the Ontario law to increase compliance inevitably involve centralization of wage determination or externally (to the firm) imposed evaluation/award programs. This is an important message, for pay equity is not costless to firms that do comply. If pay equity is adopted as a goal, any deviation from full "treatment" implies that the costs and any benefits of the program are being unfairly distributed. ${ }^{45}$

Second, the evidence here is that the law was more likely to have unintended, rather than intended, consequences. Any advantage to women in female jobs might have been at the expense of women in male jobs, who appear to have lost by the law. While inferences from a public policy intervention are in some sense specific to the jurisdiction where it occurred, the law in Ontario likely had it greatest effect among non-unionized workers in large establishments, a sector of the labor market where there is a substantial penalty to work in female jobs and that is relatively flexible.

${ }^{45}$ Other "inequities" of treatment have been reported in Iowa (Gardner and Daniel (1998), Orazem and Mattila (1990)), where pay adjustments raised individual employee's salaries above those of their supervisors. 


\section{REFERENCES}

Akerlof, George A. and Rachel E. Kranton, "Economics and Identity," Quarterly Journal of Economics, forthcoming.

Ashenfelter, Orley and Robert S. Smith, "Compliance with the Minimum Wage Law," Journal of Political Economy, April 1979, 87 (2), 333-350.

Baker, Michael and Nicole M. Fortin, "Women's Wages in Women's Work: A USCanada Comparison of the Roles of Unions and "Public Goods" Sector Jobs," American Economic Review - AEA Papers and Proceedings, May 1999, 89 (2), 198-223.

_ and __ "Occupational Gender Composition and Wages in Canada: 1987-1988," Canadian Journal of Economics, forthcoming.

Bayard, Kimberly, Judith Hellerstein, David Neumark, and Kenneth Troske, "New Evidence on Sex Segregation in Wages from Matched Employee-Employer Data," NBER Working Paper 7003, NBER: Cambridge, MA. March 1999.

Beider, Perry C., B. Douglas Bernheim, Victor R. Fuchs, and John B. Shoven, "Comparable Worth in a General Equilibrium Model of the U.S. Economy," Research in Labor Economics, 1988, 9, 1-52.

Bergmann, Barbara R., "Does The Market for Women's Labor Need Fixing?," Journal of Economic Perspectives, 1989, 3, 103-110.

Borland, Jeff, "The Equal Pay Case - Thirty Years On," Australian Economic Review, 1999, 32, 265-272.

CCH Canadian Limited, Canadian Labour Law Reporter, North York ON: CCH Canadian Limited, 1997.

Canadian Facts, "Outcomes of Pay Equity for Organizations Employing 100-499 Employees in Ontario," Report Prepared for the Policy and Research Branch of the Pay Equity Commission, Toronto March 1992.

_ , "Outcomes of Pay Equity for Organizations Employing 50-99 Employees in Ontario," Report Prepared for the Policy and Research Branch of the Pay Equity Commission, Toronto March 1993. 
Cihon, Patrick, "Comparable Worth: The Quebec Experience," Journal of Collective Negotiations in the Public Sector, 1988, 17 (3), 249-255.

Ehrenberg, Ronald G. and R.S. Smith, "Comparable Worth Wage Adjustments and Female Employment in the State and Local Sector," Journal of Labor Economics, $1987,5,43-62$.

Gardner, Susan E. and Christopher Daniel, "Implementing Comparable Worth/Pay Equity: Experiences of Cutting-Edge States," Public Personnel Management, Winter 1998, 27 (4), 475-489.

Genge, S., "Pay Equity in Canada: What Works?," Technical Report, Human Resources and Development Canada, Ottawa 1994.

Gunderson, Morley, "Gender Discrimination and Pay-Equity Legislation" in L. Christofides, K.Grant and R. Swidinsky (eds,) Aspects of Labour Market Behaviour: Essays in Honour of John Vanderkamp, Toronto: University of Toronto Press, 1995, $225-247$.

Hundley, Greg, "The Effects of Comparable Worth in the Public Sector on Public/Private Occupational Relative Wages," Journal of Human Resources, 1992, 28 (2), 318-342.

Institute for Social Research, "Pay Equity Survey of Private-Sector Organizations Employing 10-49 Employees in Ontario," Report, York University, Toronto October 1994.

Johnson, George and Gary Solon, "Estimates of the Direct Effects of Comparable Worth Policy," American Economic Review, December 1986, 76 (5), 1117-1125.

Killingsworth, Mark R., "Heterogeneous Preferences, Compensating Wage Differentials, and Comparable Worth," Quarterly Journal of Economics, November 1987, 102 (4), $727-742$.

— The Economics of Comparable Worth, Kalamazoo, MI: W.E. Upjohn Institute, 1990.

Macpherson, David A. and Barry T. Hirsch, "Wages and Gender Composition: Why Do Women's Jobs Pay Less?," Journal of Labor Economics, July 1995, 13 (3), $426-471$. 
McDonald, Judith A. and Robert J. Thornton, "Private Sector Experience with Pay Equity in Ontario," Canadian Public Policy, June 1998, 24 (2), 185-208.

O'Neill, June, Michael Brien, and James Cunningham, "Effects of Comparable Worth Policy: Evidence from Washington State," American Economic Review, May 1989, $79(2), 305-309$.

Orazem, P. and J.P. Mattila, "The Implementation Process of Comparable Worth: Winners and Losers," Journal of Political Economy, February 1990, 98, 134-152.

Piore, M. J., "Perspectives on Labor Market Flexibility," Industrial Relations, 1986, 25 (2), 147-166.

Read, Jean, "A Review of the Pay Equity Act," Prepared for the Ministry of Labour, Pay Equity Review, Ontario: Ministry of Labour 1996.

Robb, Roberta, "Equal Pay for Work of Equal Value in Ontario: An Overview," in Michael G. Abbott, ed., Pay Equity: Means and Ends, Kingston, Ontario: John Deutsch Institute for the Study of Economic Policy, 1990, pp. 33-46.

Sorensen, Elaine, "Effects of Comparable Worth Policies on Earnings," Industrial Relations, Fall 1987, 26 (3), 227-239.

SPR Associates, "An Evaluation of Pay Equity in Ontario: the First Year," Report Prepared for the Pay Equity Commission, Toronto April 1991.

Symes, Beth, "Pay Equity in Canada," in Michael G. Abbott, ed., Pay Equity: Means and Ends, Kingston, Ontario: John Deutsch Institute for the Study of Economic Policy, 1990, pp. 21-30.

Weiner, Nan and Morley Gunderson, Pay Equity: Issues, Options and Experience, Toronto: Butterworths, 1990. 
TABLE 1

Implementation Deadlines of the Ontario Pay Equity Act

\begin{tabular}{|c|c|c|c|c|}
\hline \multirow{2}{*}{$\begin{array}{l}\text { Type of Employer } \\
\text { PUBLIC SECTOR: }\end{array}$} & \multicolumn{2}{|c|}{$\begin{array}{l}\text { Deadline for Posting } \\
\text { Pay Equity Plans }\end{array}$} & \multicolumn{2}{|c|}{$\begin{array}{l}\text { Deadline for Initial } \\
\text { Pay Equity Award }\end{array}$} \\
\hline & & & & \\
\hline All Establishments & \multicolumn{2}{|c|}{1990} & \multicolumn{2}{|c|}{1990} \\
\hline \multicolumn{5}{|l|}{ PRIVATE SECTOR: } \\
\hline \multicolumn{5}{|l|}{ Larger Establishments } \\
\hline >499 Employees & \multicolumn{2}{|c|}{1990} & \multicolumn{2}{|c|}{1991} \\
\hline 100-499 Employees & \multicolumn{2}{|c|}{1991} & \multicolumn{2}{|c|}{1992} \\
\hline Smaller Establishments & "Opt In" & "Opt Out" & "Opt In" & "Opt Out" \\
\hline 50-99 Employees & 1992 & NA & 1993 & $1993^{*}$ \\
\hline 10-49 Employees & 1993 & NA & 1994 & $1994^{*}$ \\
\hline
\end{tabular}

Notes: Source: CCH Canadian Limited (1997). All deadlines were to be posted on the January 1st of the indicated year. NA is not applicable. Smaller firms had the option of opting in our out of the plan posting provisions of the legislation. For firms that opted out, the * indicates the date by which all pay equity awards were to be made (versus the initial award for firms that opted in). 
TABLE 2

Compliance with the Ontario Pay Equity Act

\begin{tabular}{|c|c|c|c|c|c|c|c|}
\hline \multirow[t]{3}{*}{ Type of Employer } & \multicolumn{7}{|c|}{ Proportion of Firms with ${ }^{a}$} \\
\hline & \multicolumn{3}{|c|}{ All Plans Posted } & \multirow{2}{*}{$\begin{array}{c}\text { Some Plans } \\
\text { Posted }\end{array}$} & \multirow{2}{*}{$\begin{array}{c}\text { Plans in } \\
\text { Development }\end{array}$} & \multirow{2}{*}{$\begin{array}{c}\text { No Work } \\
\text { Done }\end{array}$} & \multirow{2}{*}{$\begin{array}{l}\text { Not } \\
\text { Stated }\end{array}$} \\
\hline & All & Union & Non-Union & & & & \\
\hline \multicolumn{8}{|l|}{ Public Sector: } \\
\hline All Establishments & 46 & & & 24 & 12 & 10 & 8 \\
\hline (>1000 Employees) & & 12.5 & $-b$ & & & & \\
\hline (500-999 Employees) & & 20 & - & & & & \\
\hline
\end{tabular}

PRivate SEctor:

Larger Establishments

$>499$ Employees

(>1000 Employees)

(500-999 Employees)

100-499 Employees

38

38

51

26

20

4

$51 \quad 50 \quad 73$

77

77

73

15

22

6

6

Smaller Establishments

50-99 Employees

30

10-49 Employees

12

$\begin{array}{ccc}16 & 28 & 20 \\ 3 & 5 & 80\end{array}$

Notes: Source for proportions: SPR (1991), Canadian Facts $(1992,1993)$ and ISR (1994). The information was collected by telephone survey 6-12 months after the relevant posting deadline (15-18 months for private firms with 10-49 employees) with the exception of the proportion by union status for private firms with 100-499 employees. These were collected through a subsequent mail survey, the response to which was correlated with compliance.

${ }^{a}$ The reported statistics are the proportion of the firms of the relevant type and/or size who reported the indicated level of compliance with the posting deadlines for their pay equity plans.

${ }^{b}$ Too few firms in the population to calculate a relevant proportion.

${ }^{c}$ Smaller firms that "opted out" of posting a plan had to make all pay equity awards by this date. 
TABLE 3

Failure to Achieve Equity due to Lack of Male Comparators For FEMALE Jobs, By Firm SizE

\begin{tabular}{lcccc}
\hline Firm Size & \multicolumn{2}{c}{ Private Firms } & \multicolumn{2}{c}{ Public Firms } \\
\hline $\begin{array}{c}\text { \% of } \\
\text { FJC's }\end{array}$ & $\begin{array}{c}\text { \% of } \\
\text { Employees } \\
\text { in FJC's }\end{array}$ & $\begin{array}{c}\% \text { of } \\
\text { FJC's }\end{array}$ & $\begin{array}{c}\% \text { of } \\
\text { Employees } \\
\text { in FJC's }\end{array}$ \\
\hline $1000+$ & 32.3 & 33.7 & 10.3 & 14.1 \\
$500-999$ & 19.9 & 23.5 & 8.8 & 13.9 \\
$100-499$ & N.A. & N.A. & 35.8 & 37.5 \\
$50-99$ & 32.0 & 36.0 & 54.8 & 53.6 \\
$10-49$ & 21.0 & 52.0 & & \\
\hline
\end{tabular}

Notes: N.A.: not available. FJC: Female Job Class. Source for proportions: SPR (1991), Canadian Facts (1992, 1993) and ISR (1994). 
TABLE 4

Means of Selected Variables

\begin{tabular}{|c|c|c|c|c|}
\hline \multirow[b]{2}{*}{ Variable } & \multicolumn{2}{|c|}{ Ontario } & \multicolumn{2}{|c|}{ Québec } \\
\hline & $1987 / 88$ & $1997 / 98$ & $1987 / 88$ & $1997 / 98$ \\
\hline \multicolumn{5}{|l|}{ Women } \\
\hline Log Wage (1997 CAN\$) & 2.51 & 2.62 & 2.49 & 2.57 \\
\hline Age & 36.9 & 38.6 & 36.3 & 38.7 \\
\hline High School Graduate & .365 & .274 & .349 & .208 \\
\hline University Degree & .168 & .211 & .140 & .211 \\
\hline Married & .668 & .687 & .674 & .703 \\
\hline Part-time Worker & .206 & .215 & .214 & .225 \\
\hline \multicolumn{5}{|c|}{ Top Three Industrial Sectors: } \\
\hline $\begin{array}{l}\text { Medical, welfare, and } \\
\text { educational services }\end{array}$ & .269 & .292 & .310 & .300 \\
\hline Trade & .152 & .154 & .158 & .143 \\
\hline Manufacturing & .164 & .137 & .146 & .145 \\
\hline Union coverage & .322 & .283 & .431 & .402 \\
\hline Tenure & 5.61 & 7.52 & 6.72 & 8.43 \\
\hline \multicolumn{5}{|l|}{ Establishment Size: } \\
\hline$s<20$ & .338 & .330 & .364 & .339 \\
\hline $20<=s<100$ & .310 & .311 & .307 & .300 \\
\hline $100<=s<500$ & .228 & .225 & .208 & .219 \\
\hline$s>=500$ & .123 & .134 & .121 & .141 \\
\hline No. of observations & 7059 & 13807 & 4750 & 7792 \\
\hline \multicolumn{5}{|l|}{ Men } \\
\hline Log Wage (1997 CAN\$) & 2.80 & 2.82 & 2.73 & 2.74 \\
\hline Age & 37.0 & 38.6 & 37.1 & 39.1 \\
\hline High School Grad & .348 & .287 & .325 & .194 \\
\hline University Degree & .183 & .202 & .147 & .187 \\
\hline Married & .695 & .676 & .713 & .687 \\
\hline Part-time & .032 & .049 & .045 & .056 \\
\hline \multicolumn{5}{|c|}{ Top Three Industrial Sectors: } \\
\hline Manufacturing & .322 & .307 & .293 & .296 \\
\hline Trade & .144 & .158 & .152 & .155 \\
\hline $\begin{array}{l}\text { Transportation and } \\
\text { public utilities }\end{array}$ & .107 & .105 & .104 & .107 \\
\hline Union coverage & .420 & .341 & .531 & .449 \\
\hline Tenure & 8.21 & 8.71 & 8.33 & 9.32 \\
\hline \multicolumn{5}{|l|}{ Establishment Size: } \\
\hline$s<20$ & .263 & .273 & .280 & .284 \\
\hline $20<=s<100$ & .321 & .310 & .330 & .320 \\
\hline $100<=s<500$ & .256 & .240 & .258 & .240 \\
\hline$s>=500$ & .159 & .178 & .132 & .156 \\
\hline No. of observations & 8318 & 15048 & 6216 & 9104 \\
\hline
\end{tabular}

Notes: Authors' calculations from 1987 and 1988 LMAS and 1997 and 1998 November LFS. 
TABLE 5

Mean Hourly Wages and Female/Male Wage Ratio

BY JOB TYPES

\begin{tabular}{|c|c|c|c|c|c|c|c|}
\hline & \multicolumn{3}{|c|}{ Ontario } & \multicolumn{3}{|c|}{ Quebec } & \multirow[b]{2}{*}{$\begin{array}{l}\% \text { Time } \\
\text { Diff. for } \\
\text { Location }\end{array}$} \\
\hline & $\begin{array}{l}\text { Before } \\
\text { law }\end{array}$ & $\begin{array}{l}\text { After } \\
\text { law }\end{array}$ & $\begin{array}{l}\text { \% Time } \\
\text { Diff. }\end{array}$ & $\begin{array}{l}\text { Before } \\
\text { law }\end{array}$ & $\begin{array}{r}\text { After } \\
\text { law }\end{array}$ & $\begin{array}{l}\text { \% Time } \\
\text { Diff. }\end{array}$ & \\
\hline \multicolumn{8}{|c|}{ WOMEN'S WAGES: } \\
\hline All jobs & 13.87 & 15.34 & .106 & 13.39 & 14.66 & .095 & .011 \\
\hline Female jobs & 13.64 & 15.03 & .102 & 13.12 & 14.37 & .095 & .007 \\
\hline Integrated jobs & 14.05 & 15.62 & .112 & 13.95 & 15.17 & .087 & .024 \\
\hline Male jobs & 14.74 & 15.93 & .081 & 13.18 & 14.39 & .092 & -.011 \\
\hline \multicolumn{8}{|l|}{ MEN'S WAGES: } \\
\hline All jobs & 18.42 & 18.77 & .019 & 17.14 & 17.32 & .011 & .008 \\
\hline Female jobs & 16.42 & 16.66 & .015 & 16.81 & 17.21 & .024 & -.009 \\
\hline Integrated jobs & 18.79 & 19.54 & .040 & 17.68 & 18.36 & .038 & .001 \\
\hline Male jobs & 18.51 & 18.66 & .008 & 16.91 & 16.72 & -.011 & .019 \\
\hline \multicolumn{8}{|c|}{ Female/Male Wage Ratio: } \\
\hline All jobs & .753 & .817 & .085 & .781 & .846 & .083 & .002 \\
\hline Female jobs & .831 & .902 & .086 & .780 & .835 & .070 & .016 \\
\hline Integrated jobs & .748 & .799 & .069 & .789 & .826 & .047 & .022 \\
\hline Male jobs & .796 & .854 & .072 & .779 & .861 & .104 & -.032 \\
\hline $\begin{array}{l}\text { Women in female } \\
\text { men in male jobs }\end{array}$ & bs/ .737 & .805 & .093 & .776 & .859 & .108 & -.015 \\
\hline
\end{tabular}

Note: In 1997 Canadian dollars. Before the law corresponds to $1987 / 88$, after the law to $1997 / 98$. Women make up approximately $45 \%$ of the workforce Integrated jobs comprise from $(45 \%-15 \%=30 \%$ to $45 \%+15 \%=60 \%)$ of women in the occupations Female job classes are $60 \%$ or more female and male job classes are at most $30 \%$ female. 


\begin{tabular}{|c|c|c|c|c|c|c|c|}
\hline \multirow[b]{2}{*}{ Specification } & \multicolumn{3}{|c|}{ Ontario } & \multicolumn{3}{|c|}{ Quebec } & \multirow[b]{2}{*}{$\begin{array}{c}\text { Time } \\
\text { Diff. for } \\
\text { Location }\end{array}$} \\
\hline & $\begin{array}{c}\text { Before } \\
\text { law }\end{array}$ & $\begin{array}{c}\text { After } \\
\text { law }\end{array}$ & $\begin{array}{l}\text { Time } \\
\text { Diff. }\end{array}$ & $\begin{array}{r}\text { Before } \\
\text { law }\end{array}$ & $\begin{array}{r}\text { After } \\
\text { law }\end{array}$ & $\begin{array}{l}\text { Time } \\
\text { Diff. }\end{array}$ & \\
\hline \multicolumn{8}{|c|}{ 1. All Workers } \\
\hline Women: & $\begin{array}{l}-.080^{* *} \\
(.037) \\
{[7059]}\end{array}$ & $\begin{array}{l}-.108^{*} * \\
(.043) \\
{[13805]}\end{array}$ & $\begin{array}{l}-.028 \\
(.057)\end{array}$ & $\begin{array}{c}-.082^{*} \\
(.045) \\
{[4750]}\end{array}$ & $\begin{array}{l}-.115^{* *} \\
(.047) \\
{[7796]}\end{array}$ & $\begin{array}{l}-.033 \\
(.065)\end{array}$ & $\begin{array}{c}.005 \\
(.086)\end{array}$ \\
\hline Men: & $\begin{array}{l}-.099^{* *} \\
(.036) \\
{[8318]}\end{array}$ & $\begin{array}{c}-.052 \\
(.045) \\
{[15045]}\end{array}$ & $\begin{array}{c}.047 \\
(.058)\end{array}$ & $\begin{array}{r}-.026 \\
(.039) \\
{[6216]}\end{array}$ & $\begin{array}{r}-.037 \\
(.045) \\
{[9071]}\end{array}$ & $\begin{array}{c}-.011 \\
(.058)\end{array}$ & $\begin{array}{c}.060 \\
(.083)\end{array}$ \\
\hline \multicolumn{8}{|c|}{ 2. Union Workers } \\
\hline Women: & $\begin{array}{l}.100^{* *} \\
(.049) \\
{[2369]}\end{array}$ & $\begin{array}{l}.106^{* *} \\
(.044) \\
{[4248]}\end{array}$ & $\begin{array}{c}.006 \\
(.066)\end{array}$ & $\begin{array}{l}-.014 \\
(.058) \\
{[2122]}\end{array}$ & $\begin{array}{r}-.001 \\
(.055) \\
{[3307]}\end{array}$ & $\begin{array}{c}.013 \\
(.080)\end{array}$ & $\begin{array}{c}-.007 \\
(.104)\end{array}$ \\
\hline Men: & $\begin{array}{c}-.058^{*} \\
(.034) \\
{[3708]}\end{array}$ & $\begin{array}{l}-.034 \\
(.036) \\
{[5682]}\end{array}$ & $\begin{array}{c}.024 \\
(.050)\end{array}$ & $\begin{array}{r}.036 \\
(.036) \\
{[3457]}\end{array}$ & $\begin{array}{r}.012 \\
(.041) \\
{[4335]}\end{array}$ & $\begin{array}{c}-.024 \\
(.055)\end{array}$ & $\begin{array}{c}.048 \\
(.074)\end{array}$ \\
\hline \multicolumn{8}{|c|}{ 3. Non-Union Workers } \\
\hline Women: & $\begin{array}{c}-.168^{* *} \\
(.042) \\
4690\end{array}$ & $\begin{array}{c}-.208^{* *} \\
(.049) \\
9557\end{array}$ & $\begin{array}{c}-.040 \\
(.065)\end{array}$ & $\begin{array}{c}-.126^{* *} \\
(.054) \\
2628\end{array}$ & $\begin{array}{c}-.209^{* *} \\
(.050) \\
4489\end{array}$ & $\begin{array}{l}-.054 \\
(.079)\end{array}$ & $\begin{array}{c}.036 \\
(.105)\end{array}$ \\
\hline Men: & $\begin{array}{c}-.134^{*} \\
(.047) \\
4610\end{array}$ & $\begin{array}{l}-.058 \\
(.054) \\
{[9365]}\end{array}$ & $\begin{array}{c}.076 \\
(.072)\end{array}$ & $\begin{array}{r}-.078 \\
(.057) \\
{[2759]}\end{array}$ & $\begin{array}{r}-.079 \\
(057) \\
{[4736]}\end{array}$ & $\begin{array}{l}-.001 \\
(.081)\end{array}$ & $\begin{array}{c}.077 \\
(.108)\end{array}$ \\
\hline \multicolumn{8}{|c|}{ 4. Workers in Larger Establishments $(s \geq 100)$} \\
\hline Women: & $\begin{array}{r}-.039 \\
(.048) \\
{[2339]}\end{array}$ & $\begin{array}{l}-.056 \\
(.048) \\
{[4892]}\end{array}$ & $\begin{array}{c}-.017 \\
(.068)\end{array}$ & $\begin{array}{r}-.037 \\
(.061) \\
{[1470]}\end{array}$ & $\begin{array}{l}-.105^{*} \\
(.058) \\
{[2612]}\end{array}$ & $\begin{array}{l}-.068 \\
(.084)\end{array}$ & $\begin{array}{c}.051 \\
(.118)\end{array}$ \\
\hline Men: & $\begin{array}{l}-.083^{*} \\
(.043) \\
{[3477]}\end{array}$ & $\begin{array}{l}{[702]} \\
-.020 \\
(.052) \\
{[6402]}\end{array}$ & $\begin{array}{c}.063 \\
(.067)\end{array}$ & $\begin{array}{r}-.058 \\
(.045) \\
{[2383]}\end{array}$ & $\begin{array}{r}-.053 \\
(.050) \\
{[3497]}\end{array}$ & $\begin{array}{c}.005 \\
(.067)\end{array}$ & $\begin{array}{c}.058 \\
(.095)\end{array}$ \\
\hline \multicolumn{8}{|c|}{ 5. Workers in Smaller Establishments $(s<100)$} \\
\hline Women: & $\begin{array}{l}-.096^{* *} \\
(.042) \\
{[4720]}\end{array}$ & $\begin{array}{l}-.133^{* *} \\
(.049) \\
{[8913]}\end{array}$ & $\begin{array}{l}-.037 \\
(.065)\end{array}$ & $\begin{array}{l}-.114^{* *} \\
(.051) \\
{[3280]}\end{array}$ & $\begin{array}{l}-.122^{* *} \\
(.050) \\
{[5184]}\end{array}$ & $\begin{array}{l}-.008 \\
(.071)\end{array}$ & $\begin{array}{l}-.029 \\
(.096)\end{array}$ \\
\hline Men: & $\begin{array}{l}-.094^{* *} \\
(.042) \\
{[4841]}\end{array}$ & $\begin{array}{l}-.084^{*} \\
(.046) \\
{[8643]}\end{array}$ & $\begin{array}{c}.010 \\
(.062)\end{array}$ & $\begin{array}{r}.001 \\
(.045) \\
{[3833]}\end{array}$ & $\begin{array}{r}-.050 \\
(.048) \\
{[5574]}\end{array}$ & $\begin{array}{c}-.051 \\
(.066)\end{array}$ & $\begin{array}{c}.061 \\
(.091)\end{array}$ \\
\hline
\end{tabular}

Notes: Before the law corresponds to $1987 / 88$, after the law to $1997 / 98$. Other controls include a quartic in age, six education classes, dummies metropolitan area, industry(10), employment in the federal, provincial and local public service, part time work, married, tenure, union coverage and firm size (4) where appropriate. The estimates presented are from a feasible GLS strategy where the sum of the individual level (i.e., LMAS or LFS) weights (by occupation) are used as weights in the second stage). Estimated standard errors are in parentheses. Number of observations are in brackets. Double asterik $\left(^{* *}\right)$ indicates significance at the $5 \%$ level. single asterik $\left(^{*}\right)$ indicates significance at the $10 \%$ level. 
TABLE 7

Estimated Effect on Log Hourly Wages of Working in Ontario vs. Québec in 1997/98 vs. 1987/88

\begin{tabular}{|c|c|c|c|c|c|c|c|c|}
\hline \multirow[b]{2}{*}{ Sample } & \multicolumn{4}{|c|}{ Women } & \multicolumn{4}{|c|}{ Men } \\
\hline & $\begin{array}{l}\text { All } \\
\text { Jobs }\end{array}$ & $\begin{array}{l}\text { Female } \\
\text { Jobs }\end{array}$ & $\begin{array}{l}\text { Inter- } \\
\text { grated } \\
\text { Jobs }\end{array}$ & $\begin{array}{l}\text { Male } \\
\text { Jobs }\end{array}$ & $\begin{array}{l}\text { All } \\
\text { Jobs }\end{array}$ & $\begin{array}{l}\text { Female } \\
\text { Jobs }\end{array}$ & $\begin{array}{l}\text { Inter- } \\
\text { grated } \\
\text { Jobs }\end{array}$ & $\begin{array}{l}\text { Male } \\
\text { Jobs }\end{array}$ \\
\hline 1. All Workers & $\begin{array}{c}.045^{* *} \\
(.008) \\
{[32412]}\end{array}$ & $\begin{array}{c}.043^{* *} \\
(.010) \\
{[19004]}\end{array}$ & $\begin{array}{c}.064^{* *} \\
(.014) \\
{[11450]}\end{array}$ & $\begin{array}{c}.023 \\
(.029) \\
{[2958]}\end{array}$ & $\begin{array}{c}.045^{* *} \\
(.008) \\
{[38686]}\end{array}$ & $\begin{array}{l}.057^{* *} \\
(.026) \\
{[3120]}\end{array}$ & $\begin{array}{c}.053^{* *} \\
(.015) \\
{[11947]}\end{array}$ & $\begin{array}{c}.040^{* *} \\
(.009) \\
{[23619]}\end{array}$ \\
\hline $\begin{array}{l}\text { 2. Workers in Larger } \\
\text { Establishments }\end{array}$ & $\begin{array}{c}.041^{* *} \\
(.013) \\
{[11313]}\end{array}$ & $\begin{array}{l}.047^{* *} \\
(.016) \\
{[6343]}\end{array}$ & $\begin{array}{c}.071^{* *} \\
(.026) \\
{[3365]}\end{array}$ & $\begin{array}{l}-.044 \\
(.044) \\
{[1410]}\end{array}$ & $\begin{array}{c}.073^{* *} \\
(.011) \\
{[15779]}\end{array}$ & $\begin{array}{l}.060^{*} \\
(.036) \\
{[1315]}\end{array}$ & $\begin{array}{l}.071^{* *} \\
(.022) \\
{[4472]}\end{array}$ & $\begin{array}{l}.072^{* *} \\
(.013) \\
{[9992]}\end{array}$ \\
\hline $\begin{array}{l}\text { 3. Union Workers in } \\
\text { Larger Establishments }\end{array}$ & $\begin{array}{l}.027^{*} \\
(.015) \\
{[6524]}\end{array}$ & $\begin{array}{l}.029^{*} \\
(.018) \\
{[4294]}\end{array}$ & $\begin{array}{c}.032 \\
(.035) \\
{[1516]}\end{array}$ & $\begin{array}{l}.095^{* *} \\
(.048) \\
{[714]}\end{array}$ & $\begin{array}{l}.077^{* *} \\
(.012) \\
{[9904]}\end{array}$ & $\begin{array}{c}.072^{*} \\
(.022) \\
{[933]}\end{array}$ & $\begin{array}{l}.058^{* *} \\
(.026) \\
{[2295]}\end{array}$ & $\begin{array}{l}.077^{* *} \\
(.013) \\
{[6676]}\end{array}$ \\
\hline $\begin{array}{l}\text { 4. Non-Union Workers in } \\
\text { Larger Establishments }\end{array}$ & $\begin{array}{c}.045^{*} \\
(.024) \\
{[4789]}\end{array}$ & $\begin{array}{l}.083^{* *} \\
(.034) \\
{[2046]}\end{array}$ & $\begin{array}{l}.109^{* *} \\
(.038) \\
{[2047]}\end{array}$ & $\begin{array}{l}-.172^{* *} \\
(.078) \\
{[696]}\end{array}$ & $\begin{array}{l}.051^{* *} \\
(.022) \\
{[5875]}\end{array}$ & $\begin{array}{c}-.000 \\
(.081) \\
{[382]}\end{array}$ & $\begin{array}{l}.080^{* *} \\
(.037) \\
{[2177]}\end{array}$ & $\begin{array}{l}.062^{* *} \\
(.030) \\
{[3316]}\end{array}$ \\
\hline $\begin{array}{l}\text { 5. Union Workers in } \\
\text { Smaller Establishments }\end{array}$ & $\begin{array}{l}.044^{* *} \\
(.016) \\
{[5522]}\end{array}$ & $\begin{array}{l}.038^{*} \\
(.020) \\
{[3732]}\end{array}$ & $\begin{array}{c}.050 \\
(.033) \\
{[1473]}\end{array}$ & $\begin{array}{c}.096 \\
(.067) \\
{[317]}\end{array}$ & $\begin{array}{l}.038^{* *} \\
(.014) \\
{[7299]}\end{array}$ & $\begin{array}{c}.054 \\
(.054) \\
{[761]}\end{array}$ & $\begin{array}{c}.016 \\
(.029) \\
{[1853]}\end{array}$ & $\begin{array}{l}.041^{* *} \\
(.017) \\
{[4685]}\end{array}$ \\
\hline $\begin{array}{l}\text { 6. Non-Union Workers in } \\
\text { Smaller Establishments }\end{array}$ & $\begin{array}{c}.048^{* *} \\
(.012) \\
{[16577]}\end{array}$ & $\begin{array}{l}.043^{* *} \\
(.015) \\
{[8932]}\end{array}$ & $\begin{array}{c}.058^{* *} \\
(.020) \\
{[6414]}\end{array}$ & $\begin{array}{l}.092^{*} \\
(.049) \\
{[1231]}\end{array}$ & $\begin{array}{c}.010 \\
(.013) \\
{[15608]}\end{array}$ & $\begin{array}{c}.030 \\
(.053) \\
{[1044]}\end{array}$ & $\begin{array}{c}.041^{*} \\
(.024) \\
{[5622]}\end{array}$ & $\begin{array}{l}-.006 \\
(.017) \\
{[8942]}\end{array}$ \\
\hline
\end{tabular}

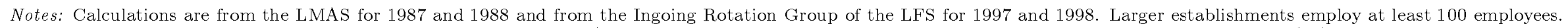

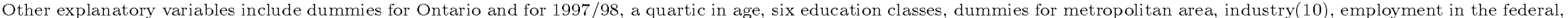

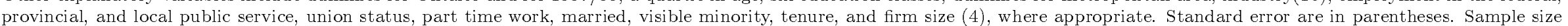
are in brackets. 
TABLE 8

Estimated Effect on Log Hourly Wages of Working in Treated Sector in 1997/98 vs. 1987/88

\begin{tabular}{|c|c|c|c|c|c|c|c|c|}
\hline \multirow[b]{2}{*}{ Sample } & \multicolumn{4}{|c|}{ Women } & \multicolumn{4}{|c|}{ Men } \\
\hline & $\begin{array}{l}\text { All } \\
\text { Jobs }\end{array}$ & $\begin{array}{l}\text { Female } \\
\text { Jobs }\end{array}$ & $\begin{array}{l}\text { Inter- } \\
\text { grated } \\
\text { Jobs }\end{array}$ & $\begin{array}{l}\text { Male } \\
\text { Jobs }\end{array}$ & $\begin{array}{l}\text { All } \\
\text { Jobs }\end{array}$ & $\begin{array}{l}\text { Female } \\
\text { Jobs }\end{array}$ & $\begin{array}{l}\text { Inter- } \\
\text { grated } \\
\text { Jobs }\end{array}$ & $\begin{array}{l}\text { Male } \\
\text { Jobs }\end{array}$ \\
\hline $\begin{array}{l}\text { A. Treated Sector: Lo } \\
\text { 1. All Workers }\end{array}$ & $\begin{array}{c}\text { stablish } \\
-.011 \\
(.017) \\
{[32412]}\end{array}$ & $\begin{array}{c}\text { s in } O n \\
.005 \\
(.021) \\
{[19004]}\end{array}$ & $\begin{array}{c}\text { vs. Qu } \\
.002 \\
(.031) \\
{[11450]}\end{array}$ & $\begin{array}{l}-.150^{*} \\
(.059) \\
{[2958]}\end{array}$ & $\begin{array}{c}.046^{* *} \\
(.016) \\
{[38686]}\end{array}$ & $\begin{array}{l}-.015 \\
(.053) \\
{[3120]}\end{array}$ & $\begin{array}{c}.044 \\
(.030) \\
{[11947]}\end{array}$ & $\begin{array}{c}.055^{* *} \\
(.019) \\
{[23619]}\end{array}$ \\
\hline 2. Union Workers & $\begin{array}{c}-.022 \\
(.022) \\
{[12046]}\end{array}$ & $\begin{array}{c}-.014 \\
(.027) \\
{[8026]}\end{array}$ & $\begin{array}{c}.029 \\
(.042) \\
{[8461]}\end{array}$ & $\begin{array}{l}-.023 \\
(.082) \\
{[1031]}\end{array}$ & $\begin{array}{c}.036^{*} \\
(.018) \\
{[17203]}\end{array}$ & $\begin{array}{c}.005 \\
(.064) \\
{[1694]}\end{array}$ & $\begin{array}{c}.046 \\
(.039) \\
{[4148]}\end{array}$ & $\begin{array}{c}.034 \\
(.021) \\
{[11361]}\end{array}$ \\
\hline 3. Non-Union Workers & $\begin{array}{c}-.016 \\
(.026) \\
{[21366]}\end{array}$ & $\begin{array}{c}.037 \\
(.037) \\
{[10978]}\end{array}$ & $\begin{array}{c}.029 \\
(.042) \\
{[8461]}\end{array}$ & $\begin{array}{l}-.316^{* *} \\
(.088) \\
{[1927]}\end{array}$ & $\begin{array}{c}.036 \\
(.026) \\
{[21483]}\end{array}$ & $\begin{array}{l}-.080 \\
(.099) \\
{[1426]}\end{array}$ & $\begin{array}{c}.041 \\
(.044) \\
{[7799]}\end{array}$ & $\begin{array}{c}.054 \\
(.033) \\
{[12258]}\end{array}$ \\
\hline $\begin{array}{l}\text { 4. White Collar } \\
\text { Non-Union Workers }\end{array}$ & $\begin{array}{c}-.017 \\
(.033) \\
{[13168]}\end{array}$ & $\begin{array}{c}.020 \\
(.040 \\
{[8246]}\end{array}$ & $\begin{array}{l}-.000 \\
(.059) \\
{[4208]}\end{array}$ & $\begin{array}{c}-.104 \\
(.146) \\
{[714]}\end{array}$ & $\begin{array}{c}.066 \\
(.041) \\
{[8185]}\end{array}$ & $\begin{array}{c}-.033 \\
(.108) \\
{[921]}\end{array}$ & $\begin{array}{c}.079 \\
(.055) \\
{[4393]}\end{array}$ & $\begin{array}{c}.113 \\
(.071) \\
{[2871]}\end{array}$ \\
\hline $\begin{array}{l}\text { 5. Blue Collar } \\
\text { Non-Union Workers }\end{array}$ & $\begin{array}{c}.031 \\
(.043) \\
{[8198]}\end{array}$ & $\begin{array}{c}.133 \\
(.091) \\
{[2732]}\end{array}$ & $\begin{array}{c}.113 \\
(.054) \\
{[4253]}\end{array}$ & $\begin{array}{l}-.339^{*} \\
(.113) \\
{[1213]}\end{array}$ & $\begin{array}{c}-.005 \\
(.034) \\
{[13298]}\end{array}$ & $\begin{array}{c}-.138 \\
(.264) \\
{[505]}\end{array}$ & $\begin{array}{l}-.065 \\
(.077) \\
{[3406]}\end{array}$ & $\begin{array}{l}.030 \\
(.037) \\
{[9387]}\end{array}$ \\
\hline $\begin{array}{l}\text { B. Treated Sector: Lo } \\
\text { 6. All Workers }\end{array}$ & $\begin{array}{c}\text { stablish } \\
.008 \\
(.010) \\
{[20866]}\end{array}$ & $\begin{array}{c}\text { s within } \\
.010 \\
(.013) \\
{[11603]}\end{array}$ & $\begin{array}{l}\text { ario } \\
\qquad \begin{array}{c}.027 \\
(.019) \\
{[7526]}\end{array}\end{array}$ & $\begin{array}{l}-.076^{*} \\
(.034) \\
{[2007]}\end{array}$ & $\begin{array}{c}.016 \\
(.010) \\
{[23366]}\end{array}$ & $\begin{array}{l}-.060^{* *} \\
(.034) \\
{[1880]}\end{array}$ & $\begin{array}{c}.007 \\
(.019) \\
{[7244]}\end{array}$ & $\begin{array}{c}.030^{*} \\
(.012) \\
{[14242]}\end{array}$ \\
\hline 7. Union Workers & $\begin{array}{l}-.008 \\
(.011) \\
{[6617]}\end{array}$ & $\begin{array}{c}.001 \\
(.018) \\
{[4385]}\end{array}$ & $\begin{array}{c}.003 \\
(.033) \\
{[1571]}\end{array}$ & $\begin{array}{l}-.105^{*} \\
(.052) \\
{[661]}\end{array}$ & $\begin{array}{c}.016 \\
(.012) \\
{[9391]}\end{array}$ & $\begin{array}{c}-.066 \\
(.045) \\
{[873]}\end{array}$ & $\begin{array}{l}.046^{* *} \\
(.026) \\
{[2222]}\end{array}$ & $\begin{array}{l}.016 \\
(.014) \\
{[6296]}\end{array}$ \\
\hline 8. Non-Union Workers & $\begin{array}{c}.028^{*} \\
(.014) \\
{[14249]}\end{array}$ & $\begin{array}{l}.033^{* *} \\
(.019) \\
{[7218]}\end{array}$ & $\begin{array}{l}.039^{* *} \\
(.023) \\
{[5685]}\end{array}$ & $\begin{array}{l}-.077^{* *} \\
(.047) \\
{[1346]}\end{array}$ & $\begin{array}{c}.016 \\
(.015) \\
{[13975]}\end{array}$ & $\begin{array}{l}-.054 \\
(.052) \\
{[1007]}\end{array}$ & $\begin{array}{l}-.003 \\
(.026) \\
{[5022]}\end{array}$ & $\begin{array}{c}.030 \\
(.019) \\
{[7946]}\end{array}$ \\
\hline
\end{tabular}


TABle 8 (CONTINUED)

\begin{tabular}{|c|c|c|c|c|c|c|c|c|}
\hline \multirow[b]{2}{*}{ Sample } & \multicolumn{4}{|c|}{ Women } & \multicolumn{4}{|c|}{ Men } \\
\hline & $\begin{array}{l}\text { All } \\
\text { Jobs }\end{array}$ & $\begin{array}{l}\text { Female } \\
\text { Jobs }\end{array}$ & $\begin{array}{l}\text { Inter- } \\
\text { grated } \\
\text { Jobs }\end{array}$ & $\begin{array}{l}\text { Male } \\
\text { Jobs }\end{array}$ & $\begin{array}{l}\text { All } \\
\text { Jobs }\end{array}$ & $\begin{array}{l}\text { Female } \\
\text { Jobs }\end{array}$ & $\begin{array}{l}\text { Inter- } \\
\text { grated } \\
\text { Jobs }\end{array}$ & $\begin{array}{l}\text { Male } \\
\text { Jobs }\end{array}$ \\
\hline \multicolumn{9}{|c|}{ B. Treated Sector: Larger Establishments within Ontario } \\
\hline $\begin{array}{l}\text { 9. White Collar } \\
\text { Non-Union Workers }\end{array}$ & $\begin{array}{c}.058^{*} \\
(.017) \\
{[8918]}\end{array}$ & $\begin{array}{c}.047^{*} \\
(.021) \\
{[5551]}\end{array}$ & $\begin{array}{l}.057^{* *} \\
(.030) \\
{[2871]}\end{array}$ & $\begin{array}{l}-.011 \\
(.081) \\
{[496]}\end{array}$ & $\begin{array}{c}.022 \\
(.023) \\
{[5509]}\end{array}$ & $\begin{array}{c}-.023 \\
(.056) \\
{[644]}\end{array}$ & $\begin{array}{c}.030 \\
(.033) \\
{[2856]}\end{array}$ & $\begin{array}{c}.027 \\
(.039) \\
{[2009]}\end{array}$ \\
\hline $\begin{array}{l}\text { 10. Blue Collar } \\
\text { Non-Union Workers }\end{array}$ & $\begin{array}{l}-.026 \\
(.024) \\
{[5331]}\end{array}$ & $\begin{array}{c}.005 \\
(.048) \\
{[1667]}\end{array}$ & $\begin{array}{c}.009 \\
(.031) \\
{[2814]}\end{array}$ & $\begin{array}{l}-.121^{*} \\
(.055) \\
{[850]}\end{array}$ & $\begin{array}{l}-.045 \\
(.019) \\
{[8466]}\end{array}$ & $\begin{array}{l}-.294^{*} \\
(.133) \\
{[363]}\end{array}$ & $\begin{array}{l}-.187^{*} \\
(.044) \\
{[2166]}\end{array}$ & $\begin{array}{c}.010 \\
(.021) \\
{[5937]}\end{array}$ \\
\hline
\end{tabular}

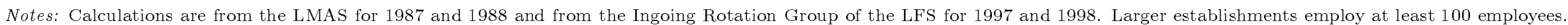

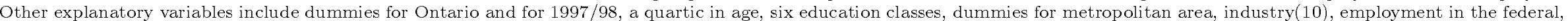

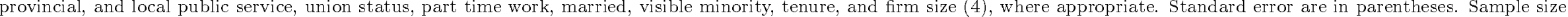
are in brackets. 
TABLE 9

Estimated Effect on The Gender Wage Gap of Working in Ontario vs. QuÉBEc IN $1997 / 98$ Vs. 1987/88

\begin{tabular}{|c|c|c|c|c|c|c|c|c|}
\hline \multirow{2}{*}{$\begin{array}{l}\text { Sample } \\
\text { Estimates for }\end{array}$} & \multicolumn{2}{|c|}{$\begin{array}{l}\text { All } \\
\text { Jobs }\end{array}$} & \multicolumn{2}{|c|}{$\begin{array}{l}\text { Female } \\
\text { Jobs }\end{array}$} & \multicolumn{2}{|c|}{$\begin{array}{l}\text { Integrated } \\
\text { Jobs }\end{array}$} & \multicolumn{2}{|c|}{$\begin{array}{l}\text { Male } \\
\text { Jobs }\end{array}$} \\
\hline & $\begin{array}{l}\text { Gender } \\
* 1997 / 98\end{array}$ & $\begin{array}{c}\text { Gender } \\
* \text { Ontario } \\
* 1997 / 98\end{array}$ & $\begin{array}{l}\text { Gender } \\
* 1997 / 98\end{array}$ & $\begin{array}{c}\text { Gender } \\
* \text { Ontario } \\
* 1997 / 98\end{array}$ & $\begin{array}{l}\text { Gender } \\
* 1997 / 98\end{array}$ & $\begin{array}{c}\text { Gender } \\
* \text { Ontario } \\
* \text { 1997/98 }\end{array}$ & $\begin{array}{c}\text { Gender } \\
* 1997 / 98\end{array}$ & $\begin{array}{c}\text { Gender } \\
* \text { Ontario } \\
* 1997 / 98\end{array}$ \\
\hline 1. All Workers & $\begin{array}{c}.059^{* *} \\
(.009) \\
{[72098]}\end{array}$ & $\begin{array}{l}.003 \\
(.011)\end{array}$ & $\begin{array}{c}.049^{* *} \\
(.010) \\
{[22124]}\end{array}$ & $\begin{array}{l}-.011 \\
(.026)\end{array}$ & $\begin{array}{c}.026 \\
(.017) \\
{[23397]}\end{array}$ & $\begin{array}{l}.015 \\
(.021)\end{array}$ & $\begin{array}{c}.058^{* *} \\
(.023) \\
{[26577]}\end{array}$ & $\begin{array}{l}-.005 \\
(.029)\end{array}$ \\
\hline $\begin{array}{l}\text { 2. Workers in } \\
\text { Larger } \\
\text { Establishments }\end{array}$ & $\begin{array}{c}.089^{* *} \\
(.014) \\
{[27092]}\end{array}$ & $\begin{array}{l}-.032^{*} \\
(.017)\end{array}$ & $\begin{array}{l}.079^{* *} \\
(.028) \\
{[7655]}\end{array}$ & $\begin{array}{c}.016 \\
(.037)\end{array}$ & $\begin{array}{l}.057^{* *} \\
(.028) \\
{[8035]}\end{array}$ & $\begin{array}{l}-.013 \\
(.034)\end{array}$ & $\begin{array}{c}.097^{* *} \\
(.034) \\
{[11402]}\end{array}$ & $\begin{array}{l}-.095^{* *} \\
(.040)\end{array}$ \\
\hline $\begin{array}{l}\text { 3. Union } \\
\text { Workers } \\
\text { in Larger } \\
\text { Establishments }\end{array}$ & $\begin{array}{c}.100^{* *} \\
(.014) \\
{[16428]}\end{array}$ & $\begin{array}{l}-.054^{* *} \\
(.019\end{array}$ & $\begin{array}{l}.108^{* *} \\
(.029) \\
{[5227]}\end{array}$ & $\begin{array}{l}-.034 \\
(.042)\end{array}$ & $\begin{array}{l}.068^{* *} \\
(.032) \\
{[3811]}\end{array}$ & $\begin{array}{l}-.033 \\
(.043)\end{array}$ & $\begin{array}{c}.013 \\
(.018) \\
{[7390]}\end{array}$ & $\begin{array}{l}.018 \\
(.045)\end{array}$ \\
\hline $\begin{array}{l}\text { 4. Non-Union } \\
\text { Workers } \\
\text { in Larger } \\
\text { Establishments }\end{array}$ & $\begin{array}{c}.068^{*} \\
(.029) \\
{[10664]}\end{array}$ & $\begin{array}{l}-.002 \\
(.026)\end{array}$ & $\begin{array}{l}-.036 \\
(.071) \\
{[2428]}\end{array}$ & $\begin{array}{l}.131 \\
(.082)\end{array}$ & $\begin{array}{c}.043 \\
(.045) \\
{[2428]}\end{array}$ & $\begin{array}{l}.010 \\
(.054)\end{array}$ & $\begin{array}{l}.193^{* *} \\
(.066) \\
{[4012]}\end{array}$ & $\begin{array}{l}-.207^{* *} \\
(.077)\end{array}$ \\
\hline Estimates for & $\begin{array}{c}\text { Gender } \\
* 1997 / 98 \\
* \text { Treated } \\
\text { Sector }\end{array}$ & $\begin{array}{c}\text { Gender } \\
* \text { Ontario } \\
* 1997 / 98 \\
* \text { Treated } \\
\text { Sector }\end{array}$ & $\begin{array}{c}\text { Gender } \\
* 1997 / 98 \\
* \text { Treated } \\
\text { Sector }\end{array}$ & $\begin{array}{c}\text { Gender } \\
* \text { Ontario } \\
* 1997 / 98 \\
* \text { Treated } \\
\text { Sector }\end{array}$ & $\begin{array}{l}\text { Gender } \\
* 1997 / 98 \\
* \text { Treated } \\
\text { Sector }\end{array}$ & $\begin{array}{c}\text { Gender } \\
* \text { Ontario } \\
* 1997 / 98 \\
* \text { Treated } \\
\text { Sector }\end{array}$ & $\begin{array}{l}\text { Gender } \\
* 1997 / 98 \\
* \text { Treated } \\
\text { Sector }\end{array}$ & $\begin{array}{c}\text { Gender } \\
* \text { Ontario } \\
* 1997 / 98 \\
* \text { Treated } \\
\text { Sector }\end{array}$ \\
\hline A. Treated & Sector: $L$ & darger csuc & ablusnmen & & & & & \\
\hline 5. All Workers & $\begin{array}{c}.046^{* *} \\
(.018) \\
{[72098]}\end{array}$ & $\begin{array}{l}-.060^{* *} \\
(.023)\end{array}$ & $\begin{array}{c}.058 \\
(.041) \\
{[22124]}\end{array}$ & $\begin{array}{c}.034 \\
(.052)\end{array}$ & $\begin{array}{c}.048 \\
(.035) \\
{[23397]}\end{array}$ & $\begin{array}{l}-.050 \\
(.044)\end{array}$ & $\begin{array}{c}.067 \\
(.048) \\
{[26577]}\end{array}$ & $\begin{array}{l}-.169^{* *} \\
(.058)\end{array}$ \\
\hline $\begin{array}{l}\text { 6. Non-Union } \\
\text { Workers }\end{array}$ & $\begin{array}{c}.063^{*} \\
(.032) \\
{[42849]}\end{array}$ & $\begin{array}{l}-.060 \\
(.038)\end{array}$ & $\begin{array}{c}-.051 \\
(.039) \\
{[12404]}\end{array}$ & $\begin{array}{l}.167 \\
(.096)\end{array}$ & $\begin{array}{c}.039 \\
(.051) \\
{[16260]}\end{array}$ & $\begin{array}{l}-.021 \\
(.062)\end{array}$ & $\begin{array}{c}.223^{* *} \\
(.076) \\
{[14185]}\end{array}$ & $\begin{array}{l}-.331^{* *} \\
(.090)\end{array}$ \\
\hline
\end{tabular}

Notes: Calculations are from the LMAS for 1987 and 1988 and from the Ingoing Rotation Group of the LFS for 1997 and 1998. Larger establishments employ at least 100 employees. Other explanatory variables include dummies for Ontario and for $1997 / 98$, a quartic in age, six education classes, dummies for metropolitan area, industry(10), employment in the federal, provincial, and local public service, union status, part time work, married, visible minority, tenure, and firm size (4), where appropriate. Standard error are in parentheses. Sample size are in brackets. 
TABLE 10

Estimated Effect on Share of Employment in Female Jobs IN Ontario vs. QueBEC IN 1997-98 Vs. 1987-88

\begin{tabular}{|c|c|c|c|c|}
\hline \multirow[b]{2}{*}{ Establishment } & \multicolumn{2}{|c|}{ Women } & \multicolumn{2}{|c|}{ Men } \\
\hline & Large & Small & Large & Small \\
\hline \multicolumn{5}{|l|}{ Sample } \\
\hline 1. All Workers & $\begin{array}{l}-.030 \\
(.017)\end{array}$ & $\begin{array}{l}.028^{* *} \\
(.013)\end{array}$ & $\begin{array}{l}-.004 \\
(.009)\end{array}$ & $\begin{array}{c}.009 \\
(.007)\end{array}$ \\
\hline 2. Union Workers & $\begin{array}{l}-.032 \\
(.021)\end{array}$ & $\begin{array}{c}.030 \\
(.024)\end{array}$ & $\begin{array}{l}-.009 \\
(.011)\end{array}$ & $\begin{array}{l}.021 \\
(.013)\end{array}$ \\
\hline 3. Non-Union Workers & $\begin{array}{c}.003 \\
(.031)\end{array}$ & $\begin{array}{l}.034^{* *} \\
(.015)\end{array}$ & $\begin{array}{c}.007 \\
(.015)\end{array}$ & $\begin{array}{c}.003 \\
(.008)\end{array}$ \\
\hline \multicolumn{5}{|c|}{ A. Treated Sector: Larger Establishments } \\
\hline 4. All Workers & $\begin{array}{l}-.052^{* *} \\
(.022)\end{array}$ & & $\begin{array}{l}-.009 \\
(.011)\end{array}$ & \\
\hline 5. Non-Union Workers & $\begin{array}{l}-.027 \\
(.034)\end{array}$ & & $\begin{array}{c}.008 \\
(.017)\end{array}$ & \\
\hline
\end{tabular}

Notes: Calculations are from the LMAS for 1987 and 1988 and from the Ingoing Rotation Group of the LFS for 1997 and 1998. Larger establishments employ at least 100 employees. Other explanatory variables include dummies for Ontario and for 1997/98, a quartic in age, six education classes, dummies for metropolitan area, industry(10), employment in the federal, provincial, and local public service, union status, part time work, married, visible minority, tenure, and firm size (4), where appropriate. Standard error are in parentheses. 
TaBle 11

Estimated Effect on Log Hourly Wages of Working in Treated Sector in 1997/98 vs. 1987/88 Holding the OCCUPational Distribution Constant

\begin{tabular}{|c|c|c|c|c|c|c|c|c|}
\hline \multirow[b]{2}{*}{ Sample } & \multicolumn{4}{|c|}{ Women } & \multicolumn{4}{|c|}{ Men } \\
\hline & $\begin{array}{l}\text { All } \\
\text { Jobs }\end{array}$ & $\begin{array}{l}\text { Female } \\
\text { Jobs }\end{array}$ & $\begin{array}{l}\text { Inter- } \\
\text { grated } \\
\text { Jobs }\end{array}$ & $\begin{array}{l}\text { Male } \\
\text { Jobs }\end{array}$ & $\begin{array}{c}\text { All } \\
\text { Jobs }\end{array}$ & $\begin{array}{l}\text { Female } \\
\text { Jobs }\end{array}$ & $\begin{array}{l}\text { Inter- } \\
\text { grated } \\
\text { Jobs }\end{array}$ & $\begin{array}{l}\text { Male } \\
\text { Jobs }\end{array}$ \\
\hline \multicolumn{9}{|c|}{ A. Treated Sector: Larger Establishments in Ontario vs. Québec } \\
\hline 1. All Workers & $\begin{array}{c}-.010 \\
(.017) \\
{[33412]}\end{array}$ & $\begin{array}{c}.005 \\
(.021) \\
{[19004]}\end{array}$ & $\begin{array}{c}.001 \\
(.031) \\
{[11450]}\end{array}$ & $\begin{array}{l}-.146^{*} \\
(.061) \\
{[2958]}\end{array}$ & $\begin{array}{c}.050 \\
(.015) \\
{[38686]}\end{array}$ & $\begin{array}{c}.027 \\
(.053) \\
{[3120]}\end{array}$ & $\begin{array}{c}.045 \\
(.031) \\
{[11947]}\end{array}$ & $\begin{array}{c}.056^{*} \\
(.019) \\
{[23619]}\end{array}$ \\
\hline 2. Non-Union Workers & $\begin{array}{c}-.005 \\
(.027) \\
{[21366]}\end{array}$ & $\begin{array}{c}.013 \\
(.038) \\
{[10978]}\end{array}$ & $\begin{array}{c}.048 \\
(.042) \\
{[8461]}\end{array}$ & $\begin{array}{l}-.319^{*} \\
(.093) \\
{[1927]}\end{array}$ & $\begin{array}{c}.081^{*} \\
(.026) \\
{[21483]}\end{array}$ & $\begin{array}{c}.085 \\
(.099) \\
{[1426]}\end{array}$ & $\begin{array}{c}.093 \\
(.045) \\
{[7799]}\end{array}$ & $\begin{array}{c}.080 \\
(.034) \\
{[12258]}\end{array}$ \\
\hline $\begin{array}{l}\text { 3. Blue Collar } \\
\text { Non-Union Workers }\end{array}$ & $\begin{array}{c}.032 \\
(.044) \\
{[8198]}\end{array}$ & $\begin{array}{c}.117 \\
(.090) \\
{[2732]}\end{array}$ & $\begin{array}{c}.117^{*} \\
(.055) \\
{[4253]}\end{array}$ & $\begin{array}{l}-.362^{*} \\
(.122) \\
{[1213]}\end{array}$ & $\begin{array}{c}-.045^{*} \\
(.016) \\
{[13298]}\end{array}$ & $\begin{array}{l}-.248^{*} \\
(.106) \\
{[505]}\end{array}$ & $\begin{array}{c}-.149^{*} \\
(.036) \\
{[3406]}\end{array}$ & $\begin{array}{l}-.003 \\
(.017) \\
{[9387]}\end{array}$ \\
\hline \multicolumn{9}{|c|}{ B. Treated Sector: Larger Establishments within Ontario } \\
\hline 4. Non-Union Workers & $\begin{array}{c}.017 \\
(.014) \\
{[14249]}\end{array}$ & $\begin{array}{c}.024 \\
(.019) \\
{[7218]}\end{array}$ & $\begin{array}{c}.051^{*} \\
(.023) \\
{[5685]}\end{array}$ & $\begin{array}{l}-.102^{*} \\
(.047) \\
{[1346]}\end{array}$ & $\begin{array}{c}.020 \\
(.015) \\
{[13975]}\end{array}$ & $\begin{array}{l}-.016 \\
(.051) \\
{[1007]}\end{array}$ & $\begin{array}{c}.008 \\
(.026) \\
{[5022]}\end{array}$ & $\begin{array}{c}.030 \\
(.019) \\
{[7946]}\end{array}$ \\
\hline $\begin{array}{l}\text { 5. Blue Collar } \\
\text { Non-Union Workers }\end{array}$ & $\begin{array}{c}-.023 \\
(.024) \\
{[5331]}\end{array}$ & $\begin{array}{c}.017 \\
(.050) \\
{[1667]}\end{array}$ & $\begin{array}{c}.017 \\
(.032) \\
{[2814]}\end{array}$ & $\begin{array}{l}-.107^{* *} \\
(.057) \\
{[850]}\end{array}$ & $\begin{array}{l}-.045 \\
(.019) \\
{[8466]}\end{array}$ & $\begin{array}{l}-.261^{* *} \\
(.133) \\
{[363]}\end{array}$ & $\begin{array}{l}-.180^{*} \\
(.045) \\
{[2166]}\end{array}$ & $\begin{array}{c}.009 \\
(.021) \\
{[5937]}\end{array}$ \\
\hline
\end{tabular}

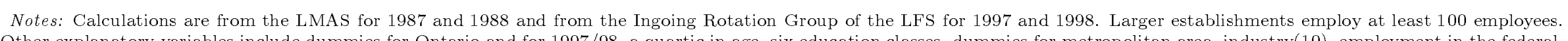

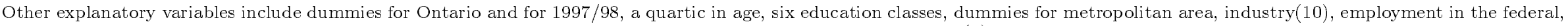

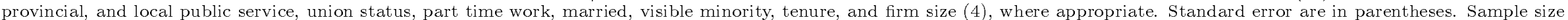
are in brackets. 
TABle $\mathrm{A}-1$

Estimated EfFect on Log Hourly Wages of Working in Treated Sector in 1997/98 vs. 1987/88 OmitTing Workers in Establishments with 20-99 Employees

\begin{tabular}{|c|c|c|c|c|c|c|c|c|}
\hline \multirow[b]{2}{*}{ Sample } & \multicolumn{4}{|c|}{ Women } & \multicolumn{4}{|c|}{ Men } \\
\hline & $\begin{array}{c}\text { All } \\
\text { Jobs }\end{array}$ & $\begin{array}{l}\text { Female } \\
\text { Jobs }\end{array}$ & $\begin{array}{l}\text { Inter- } \\
\text { grated } \\
\text { Jobs }\end{array}$ & $\begin{array}{l}\text { Male } \\
\text { Jobs }\end{array}$ & $\begin{array}{l}\text { All } \\
\text { Jobs }\end{array}$ & $\begin{array}{l}\text { Female } \\
\text { Jobs }\end{array}$ & $\begin{array}{l}\text { Inter- } \\
\text { grated } \\
\text { Jobs }\end{array}$ & $\begin{array}{l}\text { Male } \\
\text { Jobs }\end{array}$ \\
\hline \multicolumn{9}{|c|}{ A. Treated Sector: Larger Establishments in Ontario vs. Québec } \\
\hline 1. All Workers & $\begin{array}{c}-.030 \\
(.019) \\
{[23272]}\end{array}$ & $\begin{array}{c}.019 \\
(.040) \\
{[7821]}\end{array}$ & $\begin{array}{l}-.017 \\
(.035) \\
{[7948]}\end{array}$ & $\begin{array}{l}-.141^{* *} \\
(.077) \\
{[2121]}\end{array}$ & $\begin{array}{c}.030 \\
(.019) \\
{[26704]}\end{array}$ & $\begin{array}{l}-.000 \\
(.065) \\
{[2118]}\end{array}$ & $\begin{array}{c}.008 \\
(.037) \\
{[8041]}\end{array}$ & $\begin{array}{c}.044^{* *} \\
(.022) \\
{[15545]}\end{array}$ \\
\hline 2. Non-Union Workers & $\begin{array}{c}-.039 \\
(.028) \\
{[15131]}\end{array}$ & $\begin{array}{c}.037 \\
(.037) \\
{[10978]}\end{array}$ & $\begin{array}{c}.009 \\
(.044) \\
{[5990]}\end{array}$ & $\begin{array}{c}-.365^{*} \\
(.108) \\
{[1320]}\end{array}$ & $\begin{array}{c}.015 \\
(.029) \\
{[14451]}\end{array}$ & $\begin{array}{c}-.038 \\
(.110) \\
{[954]}\end{array}$ & $\begin{array}{l}-.015 \\
(.026) \\
{[5192]}\end{array}$ & $\begin{array}{c}.048 \\
(.037) \\
{[8305]}\end{array}$ \\
\hline $\begin{array}{l}\text { 3. Blue Collar } \\
\text { Non-Union Workers }\end{array}$ & $\begin{array}{c}.013 \\
(.045) \\
{[5737]}\end{array}$ & $\begin{array}{c}.157 \\
(.096) \\
{[1901]}\end{array}$ & $\begin{array}{c}.093 \\
(.055) \\
{[3032]}\end{array}$ & $\begin{array}{c}-.428^{*} \\
(.135) \\
{[804]}\end{array}$ & $\begin{array}{l}-.016 \\
(.037) \\
{[8823]}\end{array}$ & $\begin{array}{c}.088 \\
(.281) \\
{[321]}\end{array}$ & $\begin{array}{l}-.116 \\
(.029) \\
{[2208]}\end{array}$ & $\begin{array}{c}.035 \\
(.040) \\
{[6294]}\end{array}$ \\
\hline \multicolumn{9}{|c|}{ B. Treated Sector: Larger Establishments within Ontario } \\
\hline 4. All Workers & $\begin{array}{c}-.005 \\
(.012) \\
{[14477]}\end{array}$ & $\begin{array}{c}.008 \\
(.015) \\
{[7993]}\end{array}$ & $\begin{array}{c}.005 \\
(.021) \\
{[5021]}\end{array}$ & $\begin{array}{l}-.090^{*} \\
(.045) \\
{[1463]}\end{array}$ & $\begin{array}{c}.009 \\
(.012) \\
{[16311]}\end{array}$ & $\begin{array}{l}-.017 \\
(.043) \\
{[1222]}\end{array}$ & $\begin{array}{l}-.013 \\
(.023) \\
{[4905]}\end{array}$ & $\begin{array}{c}.023 \\
(.014) \\
{[10184]}\end{array}$ \\
\hline 5. Non-Union Workers & $\begin{array}{c}.012 \\
(.016) \\
{[10014]}\end{array}$ & $\begin{array}{c}.028 \\
(.021) \\
{[5098]}\end{array}$ & $\begin{array}{c}.014 \\
(.024) \\
{[3983]}\end{array}$ & $\begin{array}{c}-.089 \\
(.059) \\
{[933]}\end{array}$ & $\begin{array}{c}.003 \\
(.017) \\
{[9448]}\end{array}$ & $\begin{array}{c}-.008 \\
(.062) \\
{[649]}\end{array}$ & $\begin{array}{l}-.026 \\
(.030) \\
{[3367]}\end{array}$ & $\begin{array}{c}.013 \\
(.021) \\
{[5432]}\end{array}$ \\
\hline $\begin{array}{l}\text { 6. Blue Collar } \\
\text { Non-Union Workers }\end{array}$ & $\begin{array}{l}-.047 \\
(.026) \\
{[3671]}\end{array}$ & $\begin{array}{c}.024 \\
(.054) \\
{[1143]}\end{array}$ & $\begin{array}{c}-.018 \\
(.032) \\
{[1951]}\end{array}$ & $\begin{array}{c}-.179^{*} \\
(.069) \\
{[577]}\end{array}$ & $\begin{array}{l}-.052 \\
(.021) \\
{[5650]}\end{array}$ & $\begin{array}{c}-.083 \\
(.148) \\
{[218]}\end{array}$ & $\begin{array}{l}-.212^{* *} \\
(.047) \\
{[1407]}\end{array}$ & $\begin{array}{l}-.003 \\
(.023) \\
{[4025]}\end{array}$ \\
\hline
\end{tabular}

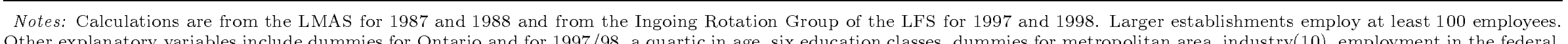

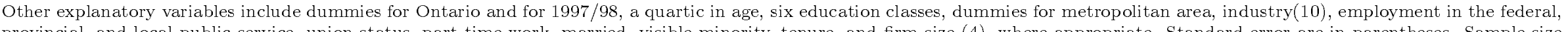

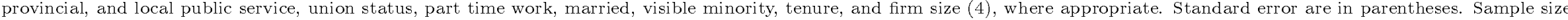
are in brackets. 

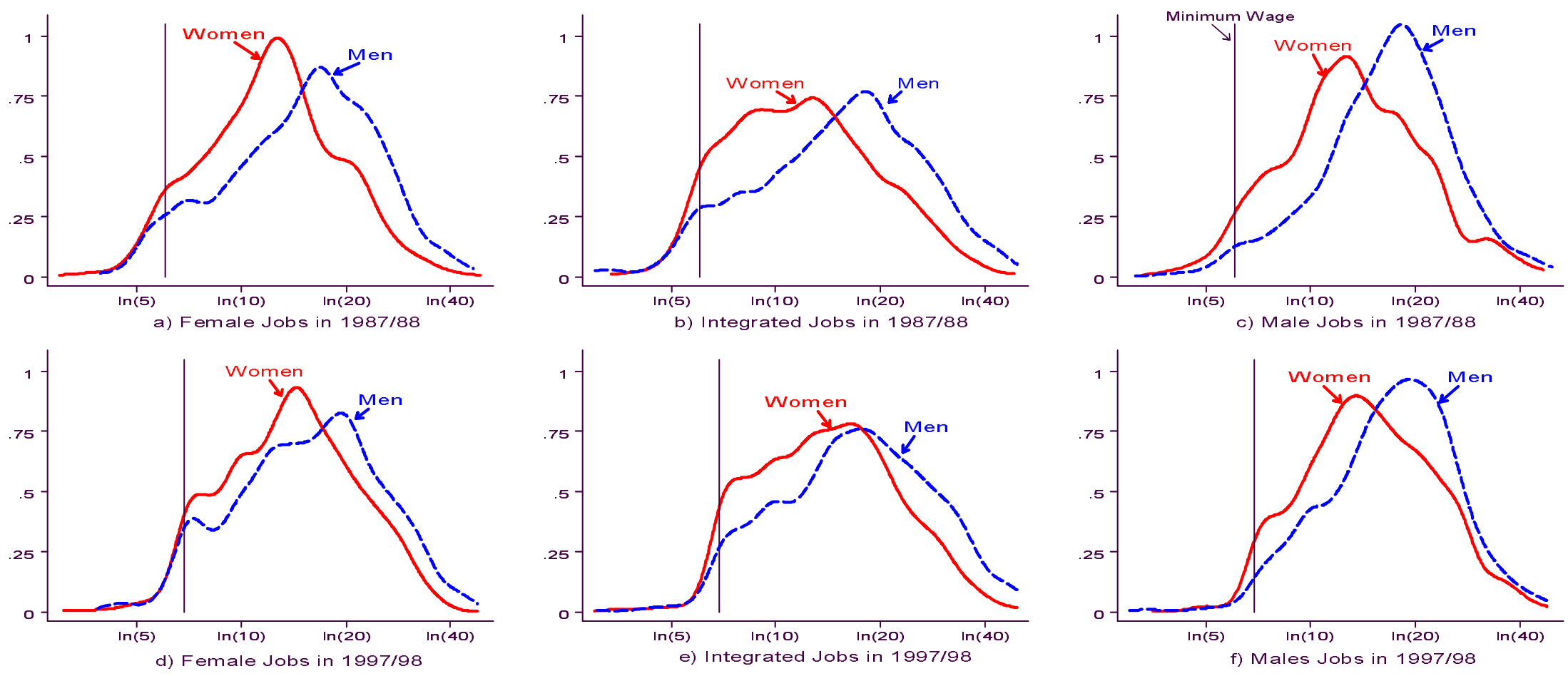

Figure 1. Differences in Women's and Men's Wage Distributions in Ontario 


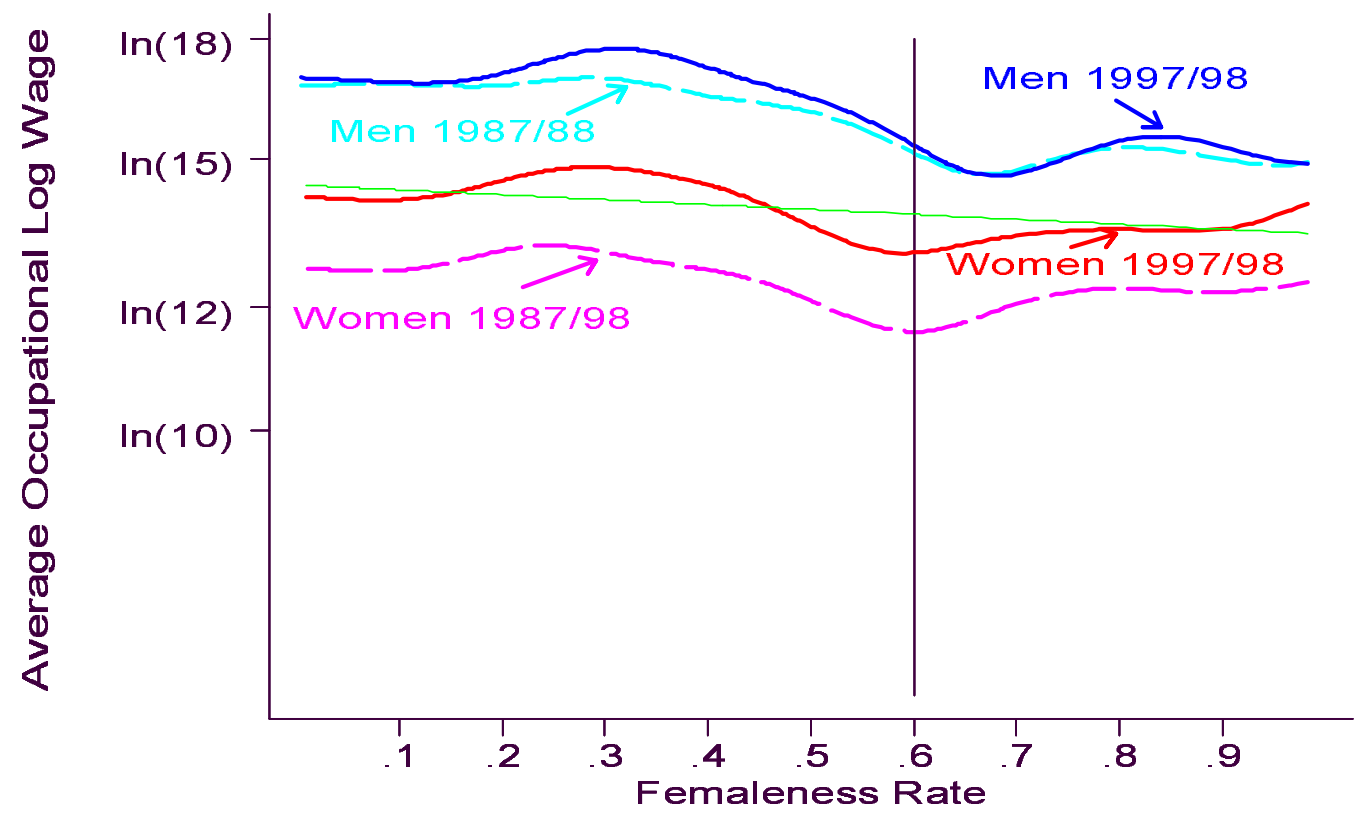

a) Ontario

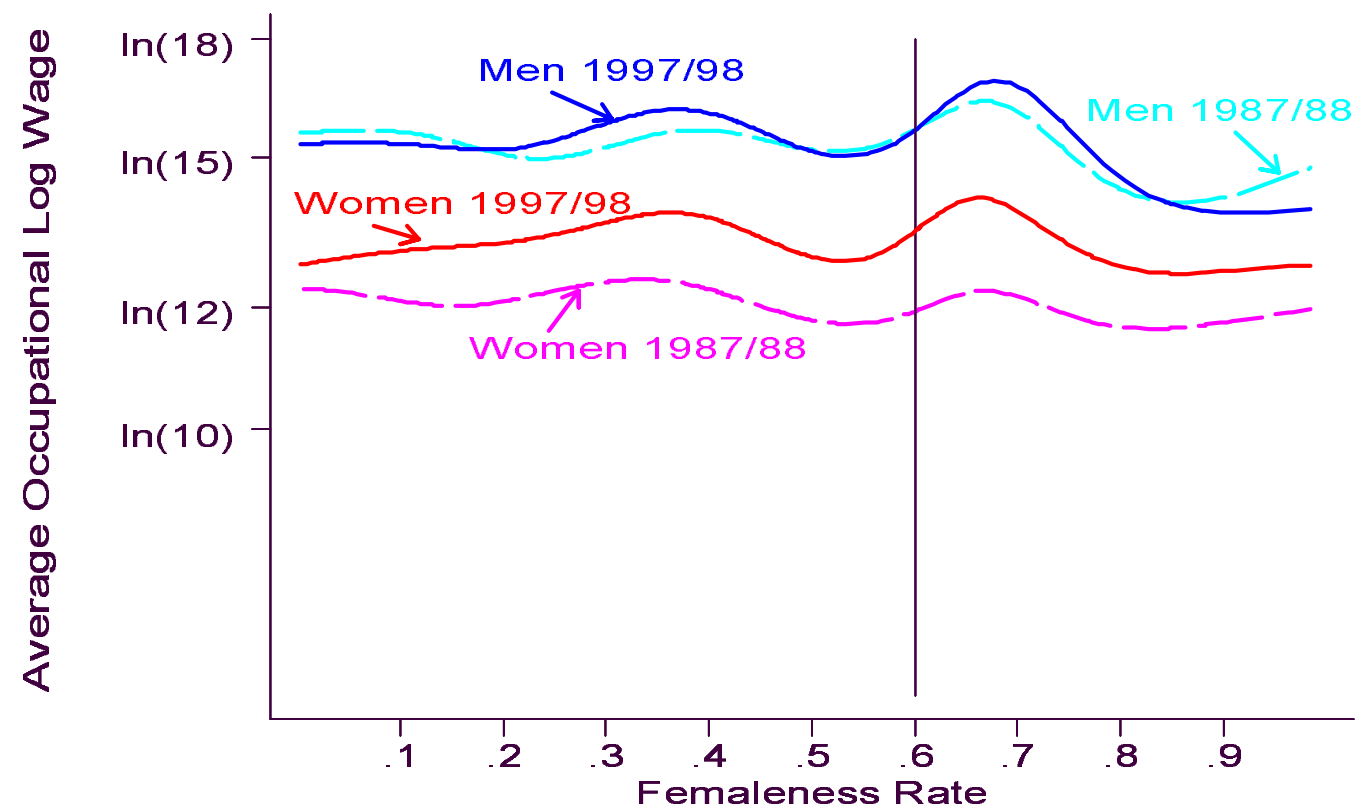

b) Quebec

Figure 2. Weighted Kernel Regressions of Average Occupational Wages on Femaleness Rates 

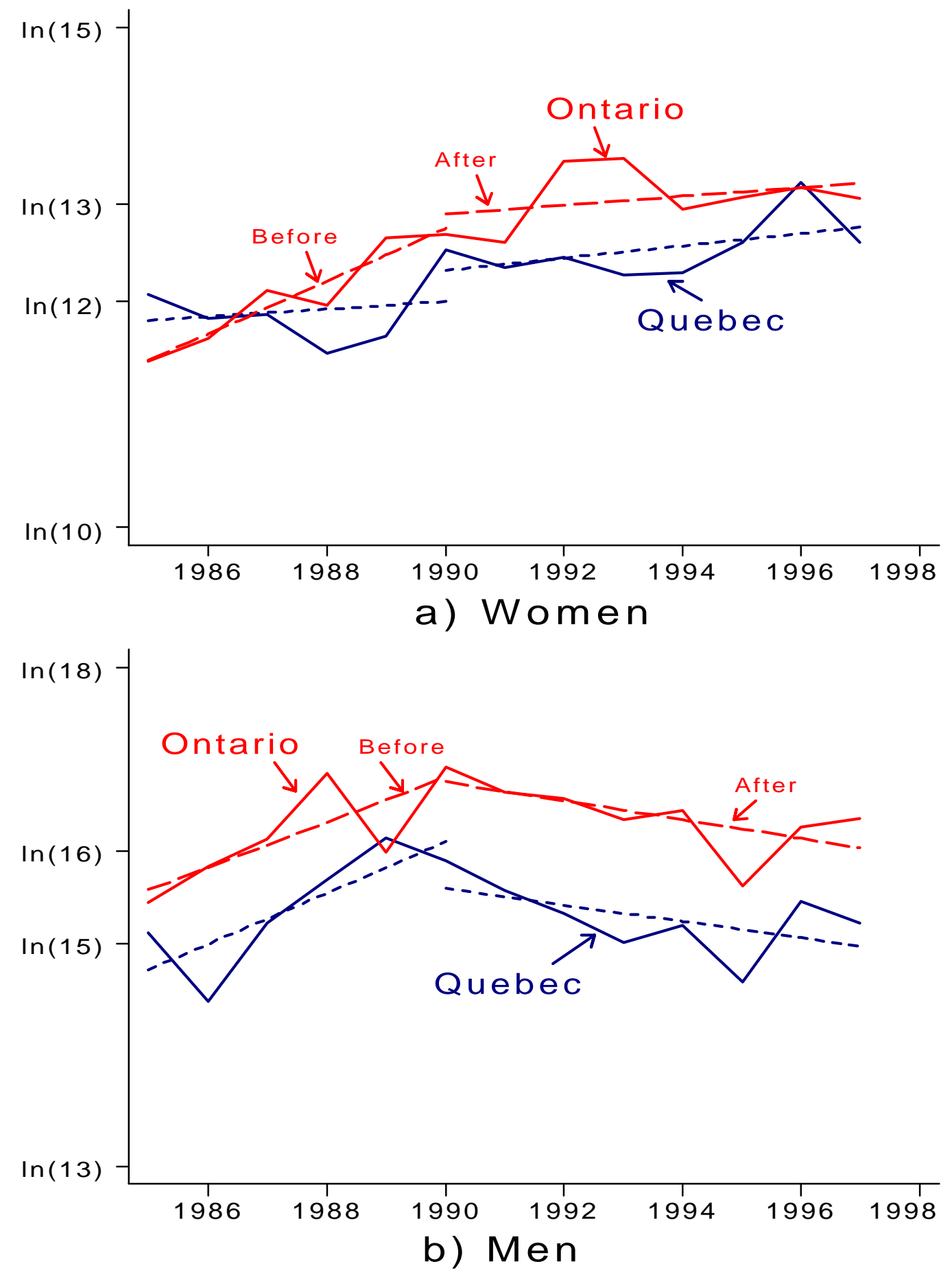

Figure 3. Average Log Hourly Wages and Trends Before and After the Law 

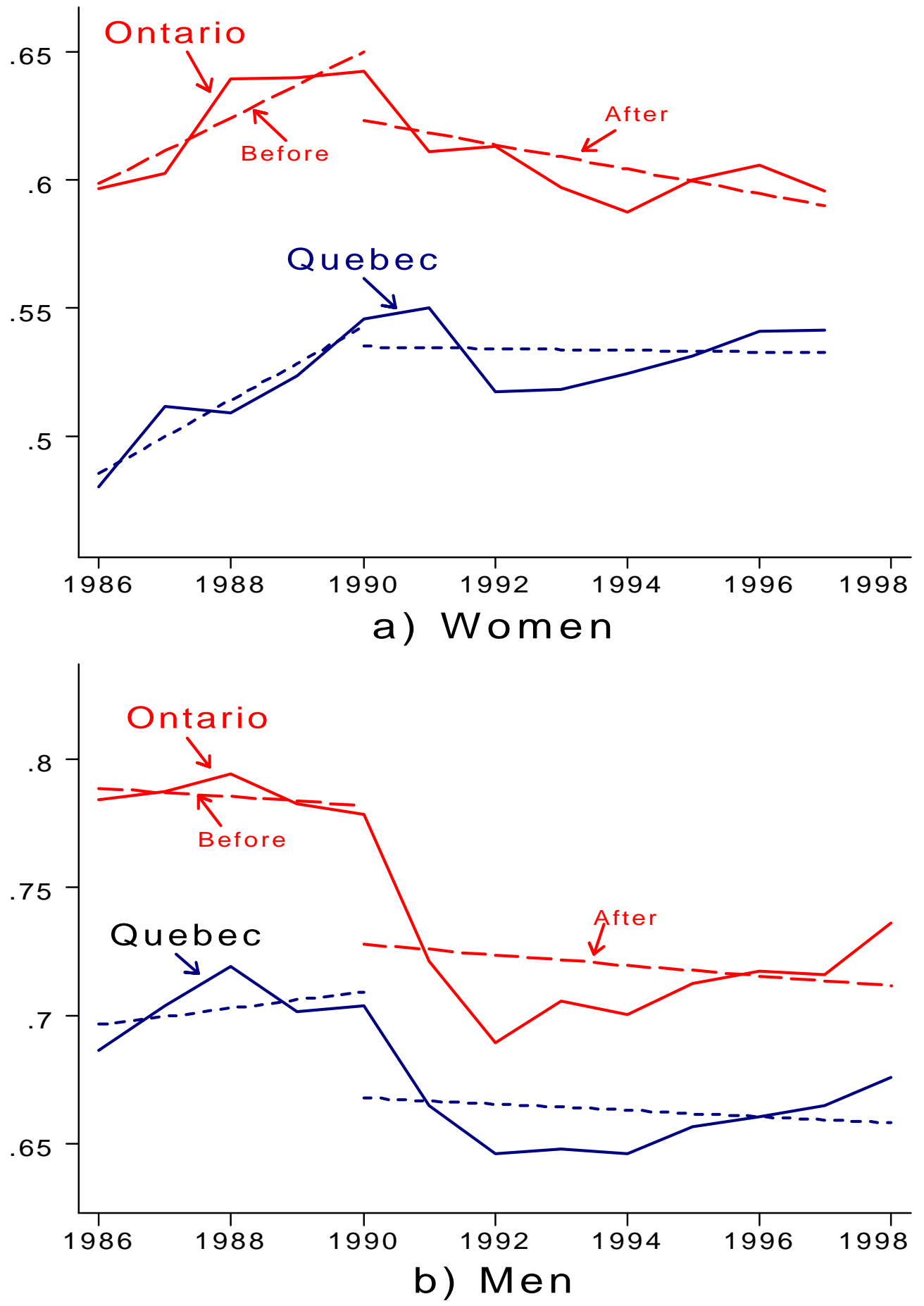

Figure 4. Employment Rates and Trends Before and After the Law 